\title{
The challenges facing Eastern Mediterranean gas and how international law can help overcome them*
}

Ana Stanič, E\&A Law Limited, London, UK. Email: anastanic@ealaw.eu; Sohbet Karbuz, Bilkent University Energy Policy Research Center, Ankara,Turkey.Email: sohbetkarbuz@, yahoo.com

(Received 5 June 2020; final version received 19 August 2020)

Enormous natural gas reserves in the Eastern Mediterranean have attracted the attention of the international energy majors. The region, however, remains one of the most under-explored and -exploited regions in the world. Numerous technical, commercial, legal and political challenges need to be overcome for these resources to be exploited and exported. This article examines the key commercial and legal challenges the region faces, and proposes possible ways to overcome these challenges by discussing the international law on the delimitation of maritime boundaries and the customary international law obligations of states in the region to resolve delimitation disputes peacefully, to make every effort to enter into provisional arrangements of a practical nature pending agreement on final delimitation and to refrain from unilaterally exploiting natural resources in disputed maritime zones.

Keywords: Eastern Mediterranean; maritime delimitation; gas; UNCLOS; export; pipelines

\section{Introduction}

The Eastern Mediterranean holds enormous natural gas reserves. As of December 2018, the natural gas reserves discovered in the region amounted to 4880 billion cubic metres (bcm). ${ }^{1}$ This exceeds the volume of natural gas discovered in Norway to date. When the total volume of gas discovered in the region and the estimated undiscovered resources are added together, the gas reserves of the Eastern Mediterranean region ${ }^{2}$ are on par with those of the North Sea region as a whole, that is, of Norway, the UK, the Netherlands and Denmark combined. ${ }^{3}$

\footnotetext{
* A shorter version of this article, discussing the key commercial challenges facing Eastern Mediterranean gas was published by the authors in OGEL earlier this year.

1 Sohbet Karbuz, 'Doğu Akdeniz'de ne Kadar Doğal Gaz Var' (2019) No.12 Bilkent Enerji Notları, Bilkent University Energy Policy Research Center Ankara https://drive.google.com/open?id= 1DLMx9kmHcB2P2cTz73jp7yEmooehSDj9 accessed 25 August 2020.

2 The region of the Eastern Mediterranean ('East Med') includes, for the purposes of this article, Egypt, Palestine, Israel, Lebanon, Syria, Cyprus, and Turkey. Unless stated otherwise, 'Cyprus' as used in this article refers to the island of Cyprus. Cyprus is de facto partitioned between the Republic of Cyprus $(\mathrm{RoC})$ in the south of the island, which has de jure sovereignty over the entire island and is a member of the European Union, and the self-declared Turkish Republic of Northern Cyprus (TRNC) in the north of the island, which is only recognised by Turkey. RoC is not recognised by Turkey and is referred to by Turkish officials as the Greek-Cypriot Administration. The EU has recognised that the government of RoC does not exercise effective control over the north of the island in a Corrigendum to Council Regulation (EC) No 866/2004 on a regime under Article 2 of Protocol 10 to the Act of Accession [2004] OJ L 206/51.

3 For a comparison of the gas reserves of the East Med with those of the North Sea using unified methodology see Karbuz (n 1).
} 
Although its enormous natural gas reserves have attracted the attention of the international energy majors, the region remains one of the most under-explored and -exploited in the world. Numerous technical, commercial, legal and political challenges must be overcome for these resources to be exploited and exported. Resolving the disputes in the region, particularly those related to maritime delimitation and the so called 'Cyprus problem', remain the most formidable challenges of all.

This article provides an overview of these challenges with a critical lens. Section 2 provides a brief overview of gas exploration and production activities in the region to date and the rising tensions these have led to. Section 3 discusses the technical challenges impeding the development of gas in region by looking at the possible routes for the export of East-Med gas. Section 4 highlights the key commercial obstacles and sections 5 and 6 examine the legal and political challenges the region faces, by focusing in particular on maritime delimitation and the continuously shifting political alliances which have led to a significant rise in tension in the region. Finally, section 7 proposes some possible ways to overcome these challenges by discussing the international law on the delimitation of maritime boundaries and the customary international law (CIL) obligations of states in the region to resolve delimitation and other disputes peacefully, to make every effort to enter into provisional arrangements of a practical nature pending agreement on final delimitation including by setting up joint development zones, and to exercise restraint in unilaterally exploiting oil and gas reserves in overlapping maritime zones.

\section{An overview of natural gas developments in the region}

More than 50 years have passed since the discovery of the first gas field in the Eastern Mediterranean, the Abu Madi field. It was discovered onshore in the Nile Delta in Egypt in 1967. In 1969, the Abu Qir gas field was discovered offshore Egypt, in the Mediterranean Sea. Following numerous other discoveries since then, Egypt became a gas exporter in 2003. Due to political instability in the country, no hydrocarbon exploration bidding rounds took place between 2011 and 2013 and Egypt became a net importer of gas in April 2015. After 2013 Egypt launched several bidding rounds and signed over 100 concession agreements for the exploration and production of gas. Successful bidding rounds and amendments to pricing policy have led to numerous discoveries. Of these, the most important is the discovery of the Zohr field in August 2015, whose recoverable reserves are estimated at 651.4 to $736.3 \mathrm{bcm}$. This, the largest gas discovery ever made in Egypt and in the Mediterranean Sea, is hailed as the game changer for gas exploration in Egypt and the region as a whole. ${ }^{4}$ Several

4 From the exploration perspective, the discovery of Zohr is a game changer. It has a completely new reservoir structure of Miocene reef carbonates, unlike the conventional sandstone formations observed in the discoveries made to date in the region. Gas production from the field began in December 2017. The other significant discoveries in the past 5 years include Baltim SW, Nour, Atoll, Nooros, Qattameya Shallow and South Disouq, among others. See Mostefa Ouki, 'Egypt - a return to a balanced gas market?' (2018) OIES Paper NG 131 www.oxfordenergy.org/wpcms/wp-content/uploads/2018/ 06/Egypt-a-return-to-a-balanced-gas-market-NG-131.pdf accessed 25 August 2020; Egyptian Natural Gas Holding Company, 'EGAS Annual Report 2018/2019' (2019) www.egas.com.eg/ annual-reports/2019 accessed 25 August 2020. 
bidding rounds, covering onshore and offshore Egypt, are expected to be launched in the near future.

There was little gas exploration in other parts of the Eastern Mediterranean until 2009. Then two giant gas fields were discovered offshore Israel in 2009 and 2010: the Tamar and Leviathan fields. ${ }^{5}$ Gas production started in the Tamar field in March 2013. Since 2016, Israel has held two international bidding rounds for the offshore exploration areas, and has awarded several blocks to foreign companies. ${ }^{6}$ By January 2017, Israel had started exporting small quantities of gas to Jordan from the Tamar field. Due to numerous political and regulatory obstacles as well as numerous legal challenges, ${ }^{7}$ gas production from the Leviathan field only started at the end of 2019, nearly a decade after its discovery. In addition to supplying the Israeli market, gas from the field started to flow to Jordan on 1 January 2020, and to Egypt on 15 January 2020. Production from the other significant Israeli gas discoveries, namely the Karish and Tanin fields, is expected to commence in the near future: Karish in the first half of 2021 and Tanin soon thereafter. The approval by the Israeli parliament of the new gas sector framework in 2015 and $2016^{8}$ paved the way for a resurgence of exploration activity (Figure 1). ${ }^{9}$

The Republic of Cypress (RoC) held offshore hydrocarbons exploration licensing rounds in 2007, 2012 and 2016 and has awarded nine blocks to international energy companies. ${ }^{10}$ Notably absent from the list of successful bidders in the first two licensing rounds were the five blocks which Turkey claims partly fall within its continental shelf (CS) albeit 'bids were reportedly received for some of these blocks' ${ }^{11}$ Then in 2016 RoC awarded block 6, part of which Turkey claims fall within its CS to an Eni-Total consortium (see Figure 2). In September 2019 block 7, also disputed by Turkey, was awarded to the same consortium. ${ }^{12}$

Noble Energy's discovery of the Aphrodite offshore gas field in December 2011 was hailed as the gamechanger for gas exploration in Cyprus. ${ }^{13}$ However, the field

5 The Tamar field has estimated reserves of $337 \mathrm{bcm}$. The Leviathan field has estimated resources of $613 \mathrm{bcm}$. For more information see Delek Group, Periodic Report for 2018 (2019) https://ir.delekgroup.com/static-files/600b0cfl-d4c3-4973-9a90-ff4e99a67f35 accessed 25 August 2020.

6 For more information see www.energy-sea.gov.il accessed 25 August 2020.

7 Including the recent unsuccessful attempt by environmental groups and municipalities located near where the pipeline comes onshore to have the production platform built further out to sea; see Editorial, 'Update 1 - Israel Court Lifts Injunction against Leviathan Gas Field Operation' CNBS (19 December 2019) www.cnbc.com/2019/12/19/reuters-america-update-1-israel-court-lifts-injunction-againstleviathan-gas-field-operation.html accessed 25 August 2020.

8 For details see Israeli Ministry of Energy, Policy and Government Decisions www.energy-sea.gov.il/ English-Site/Pages/Regulation/Policy.aspx accessed 25 August 2020.

9 Israeli Ministry of Energy www.gov.il/BlobFolder/news/os_300719/he/gas_fields.pdf accessed 25 August 2020.

10 For further details of the rounds see Cypriot Ministry of Energy, Commerce and Industry, 'Licensing Rounds' www.mcit.gov.cy/mcit/hydrocarbon.nsf/page18_en/page18_en?OpenDocument accessed 25 August 2020.

11 Ayla Gürel, Fiona Mullen, and Harry Tzimitras, The Cyprus Hydrocarbons Issue: Context, Positions and Future Scenarios, Prio (PCC Report 1/2013, Prio 2013) 5. www.prio.org/Global/upload/Cyprus/ Publications/Hydrocarbons Report-ENG.pdf accessed 25 August 2020.

12 Cyprus Hydrocarbons Company, 'Block 7 License Award' (18 September 2019) https://chc.com.cy/ 2019/09/18/block-7-licence-award accessed 25 August 2020.

13 When discovered, the field was estimated to contain 140 to $200 \mathrm{bcm}$ of gas. In 2014 , its estimated resource base was revised downwards to $128 \mathrm{bcm}$. 
GAS FIELDS \& EXPLORATION

LICENSES OFFSHORE ISRAEL

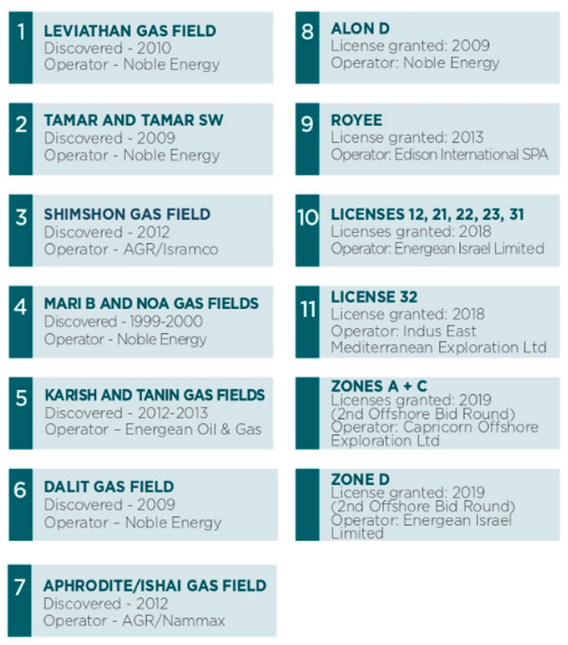

\section{UPDATED MAP OF ISRAEL'S EEZ AFTER COMPLETION OF 2ND OFFSHORE BID ROUND}

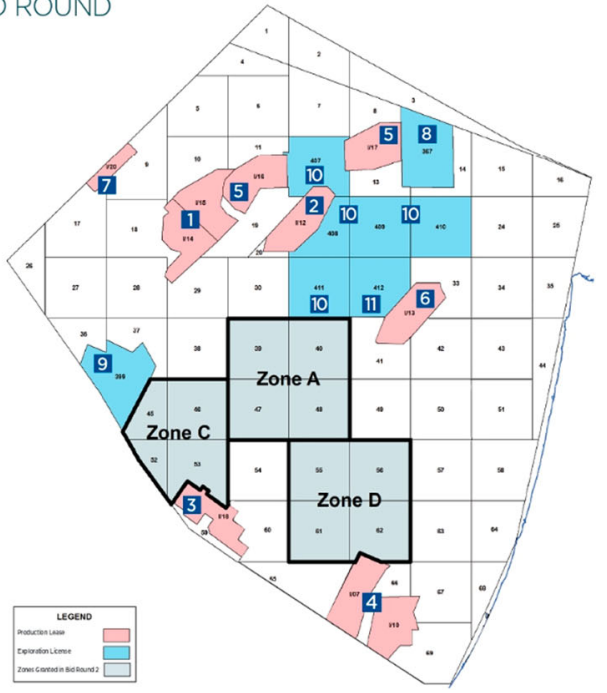

Figure 1. exploration and production licences offshore Israel.

Source: Israeli Ministry of Energy.

has not yet been developed primarily because of the lack of gas infrastructure from the field, the failure to come to a unitisation agreement with Israel, ${ }^{14}$ and delays in obtaining government approval of the development plans for the field. In 2018 the Calypso gas field was discovered by Total and Eni. In February 2019 ExxonMobil discovered an in-place natural gas resource of approximately $142-227 \mathrm{bcm}$ in the Glaucus field (see Figure 2). ${ }^{15}$

Planned drilling campaigns in 2020 offshore Cyprus are currently delayed as companies slash their capital expenditures due to COVID-19. ${ }^{16}$ The final investment decision for the Aphrodite field, which was planned to be taken by 2022, could also be negatively affected (see Figure 2). Should this happen, the first gas production from this field, currently scheduled for 2025, could be further delayed.

14 Discussions on the terms of a unitisation agreement started in 2010. In summer 2016 expectations were that an agreement was imminent. In late 2018, it seemed the countries had reached an agreement to refer the dispute over their percentage shares of the gas field to international arbitration. No progress has been made since then. For further information see eg Mona Sukkarieh, 'Aphrodite's blues' Executive Magazine (6 June 2018) www.executive-magazine.com/economics-policy/aphrodites-blues accessed 25 August 2020.

15 According to ExxonMobil this was the world's third biggest natural gas discovery in two years. See ExxonMobil, 'ExxonMobil Makes Natural Gas Discovery Offshore Cyprus' (2019). https:// corporate.exxonmobil.com/News/Newsroom/News-releases/2019/0228_ExxonMobil-makes-naturalgas-discovery-offshore-Cyprus accessed 25 August 2020.

16 For instance, ExxonMobil as well as Total-Eni consortium have already announced the postponement of their drilling campaign by a year or so. See MEES, vol. 63, no. 1617 (2020). See also Elias Hazao, 'Eni and Total Drilling Officially on Hold for One Year' Cyprus Mail (1 June 2020) https://cyprus-mail. com/2020/05/04/eni-and-total-drillings-officially-on-hold-for-one-year accessed 25 August 2020. 


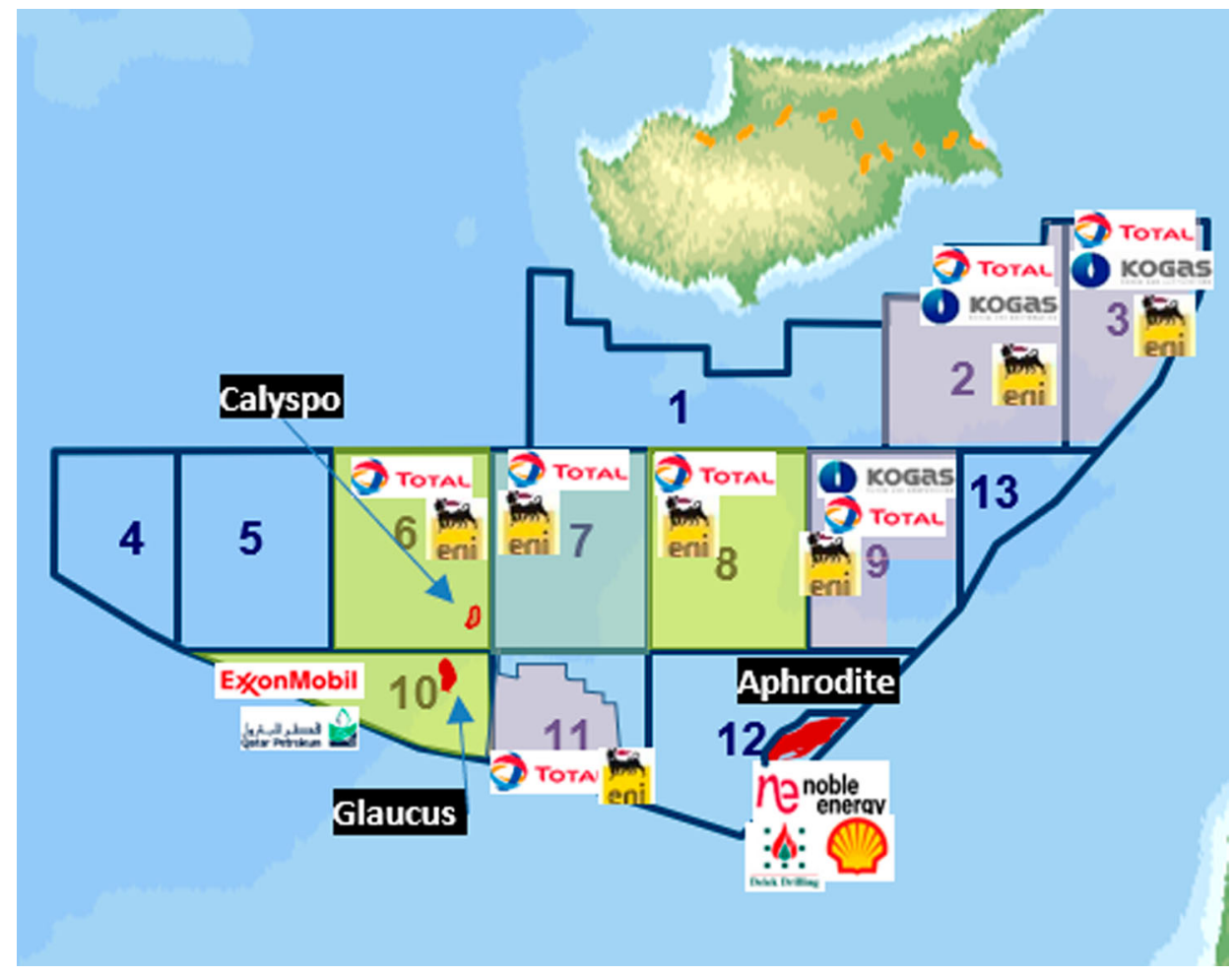

Figure 2. offshore exploration licences granted by the Republic of Cyprus and gas discoveries to date.

Source: own elaboration of the second author.

The Turkish Republic of Northern Cyprus (TRNC) signed a production sharing agreement in 2011 with Turkey's state-owned Turkish Petroleum Corporation (TPAO) for one onshore and six offshore blocks around the island of Cyprus. Although onshore and offshore drilling has so far not identified any significant resources, TPAO continues to perform seismic surveys and drilling operations around the island. As discussed in section 6, RoC has objected to these activities as have the EU and the USA.

In Palestine gas exploration activities have been very limited to date. A small offshore field, the Gaza Marine field, was discovered by British Gas (now Shell) in 1999. It is estimated to hold $28 \mathrm{bcm}$ of recoverable gas reserves. ${ }^{17}$ In 2000, British Gas commenced exploratory discussions for the sale of the gas to the Israel Electric Corporation. However, these discussions were blocked by Israel in $2001 .{ }^{18}$ The renewed discussions in 2007 and 2011 failed. Given the continued blockade of Palestine's access to the gas

17 Simon Henderson, 'Natural Gas in the Palestinian Authority: The Potential of the Gaza Marine Offshore Field' (2014) Policy Brief, The German Marshall Fund of the United States www. washingtoninstitute.org/uploads/Documents/opeds/Henderson20140301-GermanMarshallFund.pdf accessed 25 August 2020.

18 See Anaïs Antreasyan, 'Gas Finds in the Eastern Mediterranean: Gaza, Israel, and Other Conflicts' (2013) 42(3) Journal of Palestine Studies 29, 32. 
field by Israel and the political divisions amongst Palestinians the field remains undeveloped. $^{19}$

To date, Lebanon has launched two offshore licensing rounds. The first round, launched in 2012, was postponed five times. Two blocks were awarded in December $2017 .^{20}$ In the second licensing round, launched in 2019, five blocks are on offer. The deadline for submitting bids was 1 June $2020 .{ }^{21}$ However, on 31 May 2020, Minister of Energy and Water, Raymond Ghajar, announced that the deadline has been temporarily suspended due to the coronavirus pandemic and its economic repercussions. The minister indicated that the date will be reset based on the recommendation of the Petroleum Sector Management Authority, with the aim of completing the round before the end of 2021. ${ }^{22}$ Lebanon's first offshore well (Byblos 1, in block 4), drilled in early 2020, found no commercial reservoir (see Figure 3). Drilling activities in block 9 are scheduled for $2021 .^{23}$

Syria's offshore exploration is in its early stages. No licences were awarded after the first offshore licensing round was held in 2007. The second offshore exploration licensing round for three blocks was held in 2011 but no bids were submitted as war broke out in the country soon thereafter. In December 2013, whilst the war was still in full swing, the Syrian government signed a 25-year agreement with SoyuzNefteGaz (a Russian company) for the exploration of block 2 . As of the writing of this article, drilling activities had not started. With conflict still raging in the country, any significant development of upstream activities seems unrealistic in the near future.

To date, TPAO has drilled more than a dozen wells in Turkey's Mediterranean CS. In 2017 Turkey announced a more active engagement in offshore oil and gas exploration and outlined its seismic studies and drilling operations in its National Energy and Mine Policy. ${ }^{24}$ In 2019 TPAO conducted several exploratory drilling activities in areas claimed by Turkey to be in its CS which RoC claims falls within its exclusive economic zone (EEZ) (see Figure 8). In May 2020 TPAO conducted further exploratory drilling activities in block 6 as claimed by $\mathrm{RoC}^{25}$ As discussed in section 6 further drilling activities were conducted by TPAO at the end of July near the Greek island of

19 Charles Ellinas, Harry Tzimitras, and John Roberts, Hydrocarbon Developments in the Eastern Mediterranean: The Case for Pragmatism (Atlantic Council, Global Energy Center, Washington, DC and Dinu Patriciu Eurasia Center 2016) www.atlanticcouncil.org/in-depth-research-reports/report/ hydrocarbon-developments-in-the-eastern-mediterranean accessed 25 August 2020.

20 On 14 December 2017, the Council of Ministers approved the awarding of two exclusive petroleum licences for exploration and production in blocks 4 and 9 for the consortium composed of Total SA, Eni International BV and JSC Novatek.

21 The Lebanese Petroleum Administration, 'Second licensing round timeline' www.lpa.gov.lb/english/ licensing-rounds/second-licencing-round/timeline1 accessed 25 August 2020.

22 National News Agency, 'Ghajar: Deadline for Submitting Applications for Second Licensing Round Postponed' (31 May 2020) http://nna-leb.gov.lb/en/show-news/116005/Ghajar-Deadline-forsubmitting-applications-for-second-licensing-round-postponed accessed 25 August 2020.

23 Lebanese Petroleum Administration, 'Minister of Energy and Water holds a press conference announcing the completion of drilling activities in Block 4' (27 April 2020) www.lpa.gov.lb/english/newsamp-media/news/minister-of-energy-and-water-holds-a-press-conference-announcing-the-completionof-drilling-activities-in-block-4 accessed 25 August 2020.

24 Erdal T. Karagöl and others, 'National Energy and Mining Policy of Turkey' (2017) Analysis No.75 SETAV https://setav.org/en/assets/uploads/2017/08/Analysis35.pdf accessed 25 August 2020.

25 Stuart Elliot, 'EU foreign ministers slam continued Turkish gas drilling offshore Cyprus' S\&P Global Platts (18 May 2020) www.spglobal.com/platts/en/market-insights/latest-news/natural-gas/051820-euforeign-ministers-slam-continued-turkish-gas-drilling-offshore-cyprus accessed 25 August 2020. 


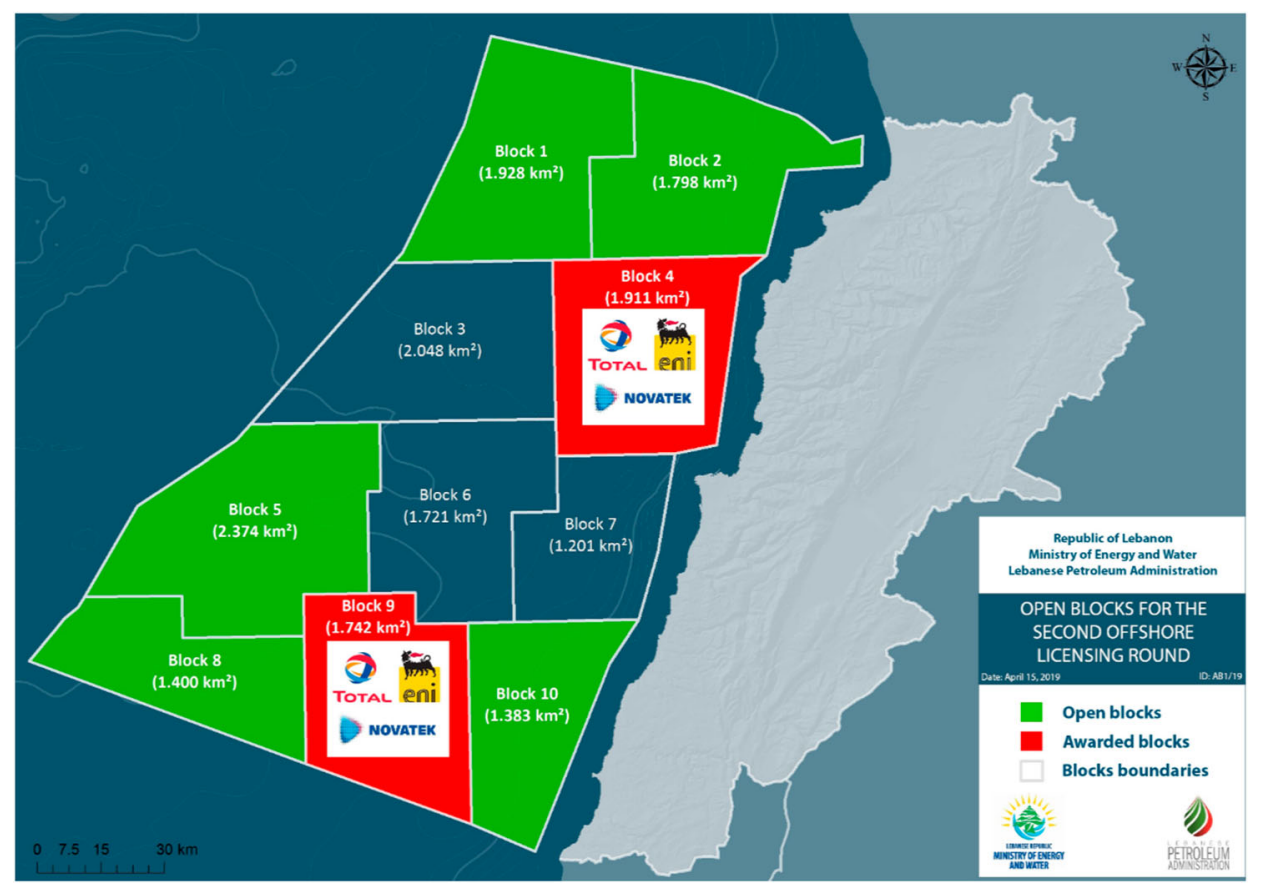

Figure 3. open and awarded blocks offshore Lebanon.

Source: www.lpa.gov.lb/english/licensing-rounds/second-licencing-round/open-blocks1.

Kastellorizo and in early August between the island of Crete and Cyprus, in areas of the Mediterranean Sea claimed by both. None of the wells drilled so far contained commercial quantities of hydrocarbons.

The natural gas discoveries in the Eastern Mediterranean in the past decade are shown in Figure 4. By the end of 2019 more than $2400 \mathrm{bcm}$ of gas had been discovered in the region. This is equivalent to the total gas reserves of Azerbaijan. Some of these discoveries, namely of the Tamar field in 2009, the Leviathan field in Israel 2010, and the Zohr field in Egypt in 2015, were among the world's largest deep-water gas discoveries in the 2000s. These discoveries sparked the interest of international energy majors and a gas bonanza was predicted. ${ }^{26}$

\section{Export challenges facing gas production in the region}

According to the Observatoire Méditerranéen de l'Energie (OME)'s reference scenario (RS), the total gas export potential of the Eastern Mediterranean will reach $30 \mathrm{bcm}$ per year in 2030 (see Figure 5), of which at least $19 \mathrm{bcm}$ could be exported in the form of liquefied natural gas (LNG). On a country-by-country basis, OME considers it likely

26 Aditya Saraswat, 'Fun in the Sun for Club Med Upstream Oil and Gas Operator' (2019) Vol 16 No. 3 GEO ExPro www.geoexpro.com/articles/2019/06/fun-in-the-sun-for-club-med-upstream-oil-and-gasoperators accessed 25 August 2020. Note: 1 million barrels of oil equivalent corresponds to $0.17 \mathrm{bcm}$ of gas. 


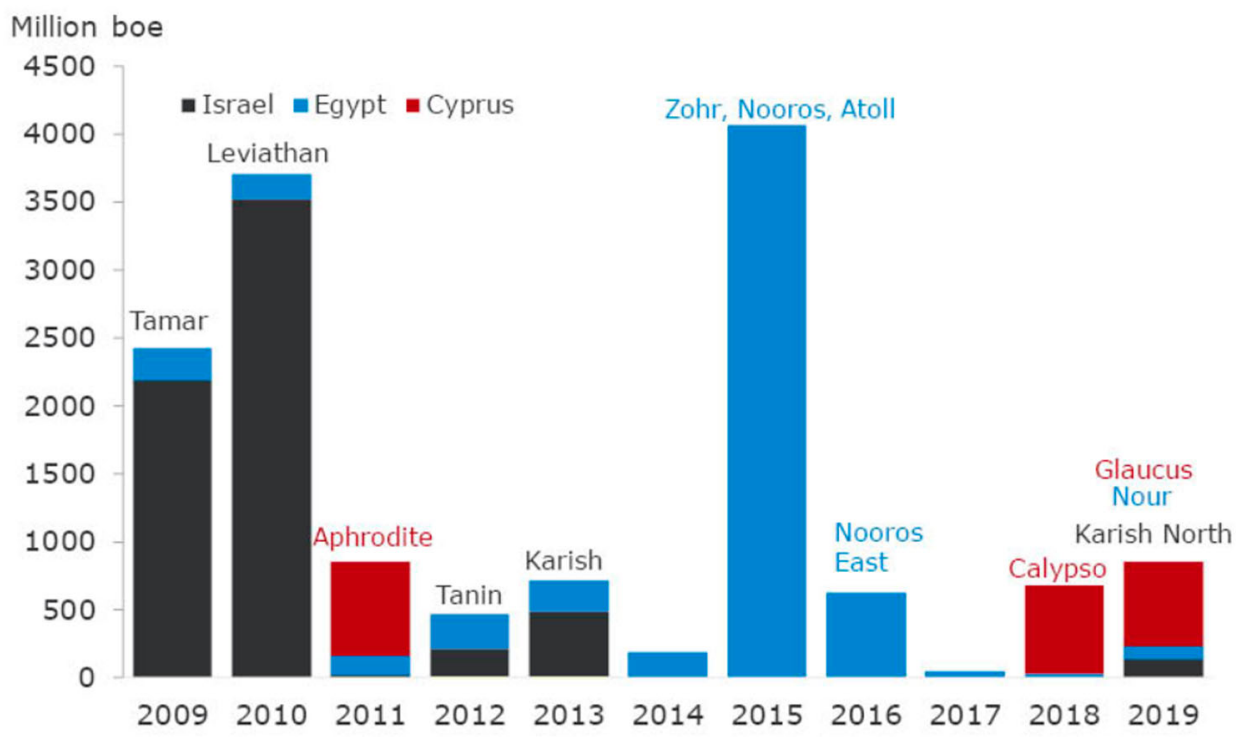

Figure 4. natural gas discoveries in the Eastern Mediterranean in the past decade. Reproduced by kind permission of the GEO ExPro Magazine.

Source: GEO ExPRo Magazine/Rystad Energy.

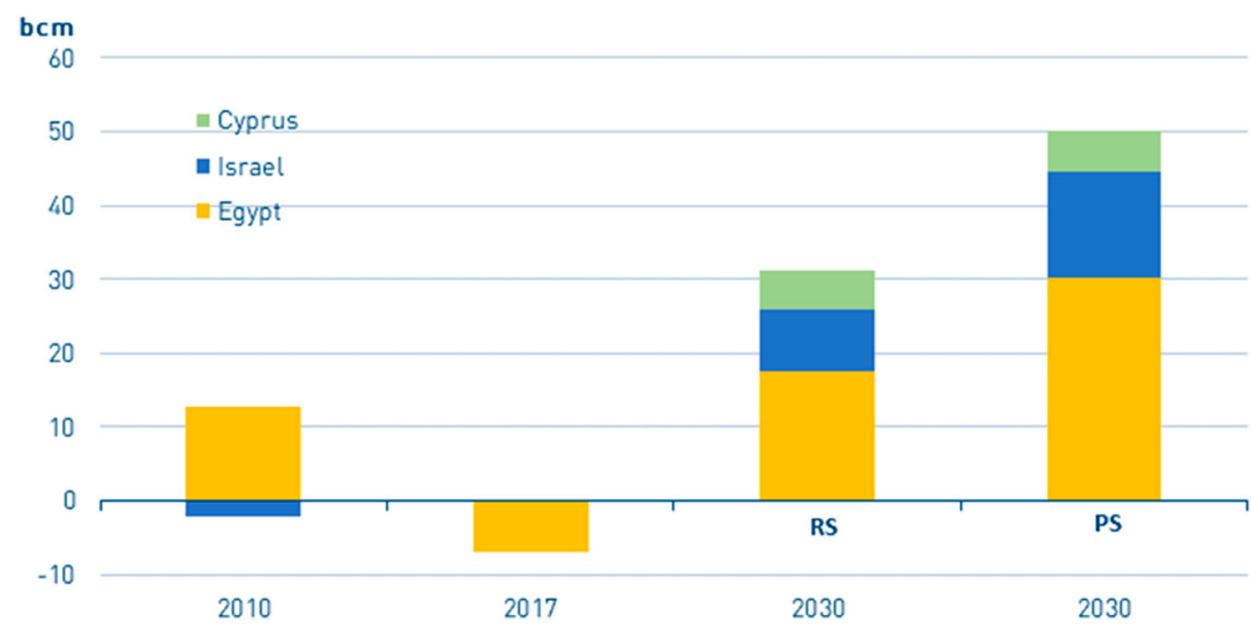

Figure 5. gas export potential of the countries in the Eastern Mediterranean. Reproduced by kind permission of Observatoire Méditerranéen de l'Energien.

Source: OME, Mediterranean Energy Perspective 2018, Paris.

that Egypt's export potential will approach $20 \mathrm{bcm} / \mathrm{yr}$ by the mid-2020s. The gas export potential of Israel is expected to peak in the late 2020 s at less than $10 \mathrm{bcm} / \mathrm{yr}$ in the RS reference scenario.

In the alternative scenario (PS), which assumes that the countries in the region implement aggressive energy efficiency measures and adopt ambitious renewable energy policies, OME estimates that the total gas export potential of the region could rise to $50 \mathrm{bcm} / \mathrm{yr}$ (see Figure 5). In this scenario, the export potential of Egypt would exceed $30 \mathrm{bcm} / \mathrm{yr}$, Israel's would peak in the mid-2030s at above $15 \mathrm{bcm} / \mathrm{yr}$ and 


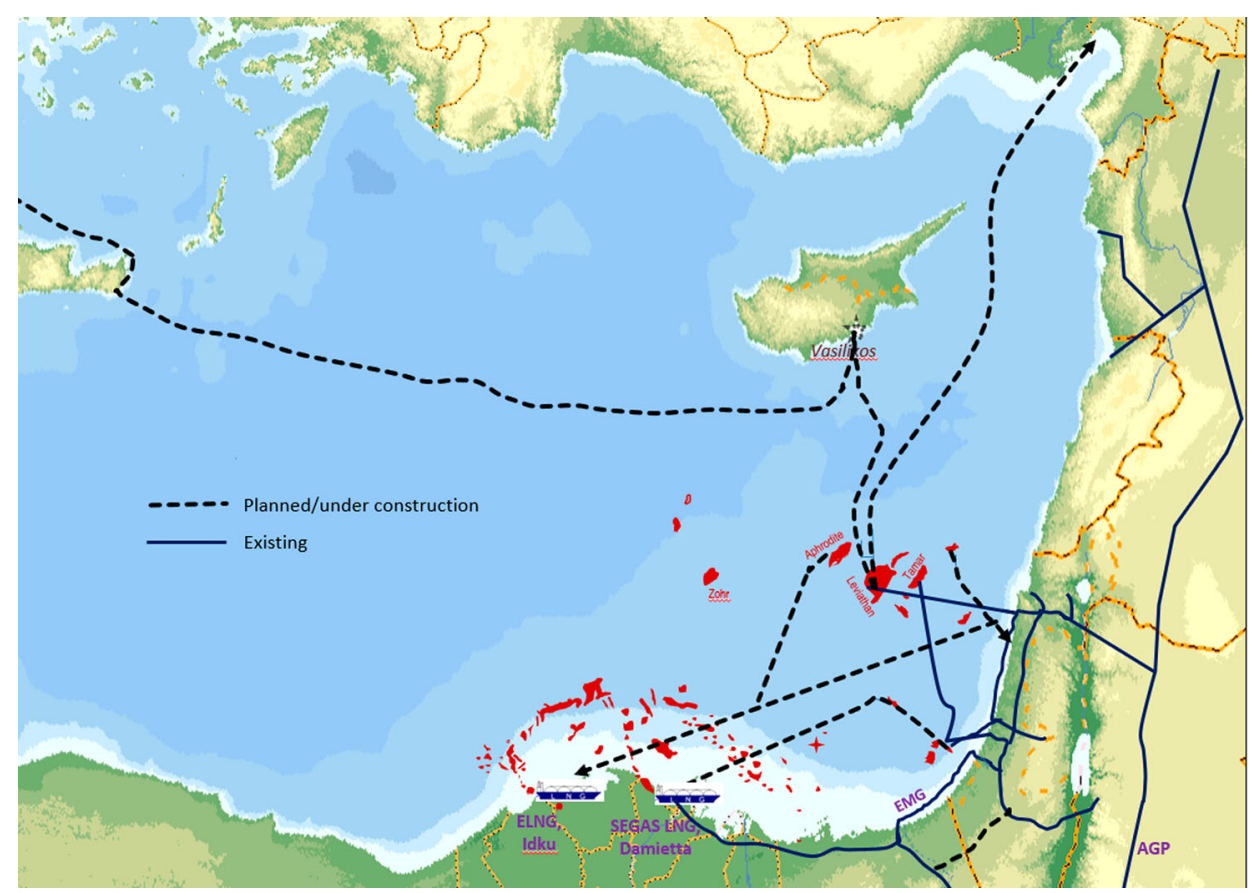

Figure 6. gas export infrastructure in East Mediterranean. Source: own elaboration of the second author.

Cyprus could add another $5 \mathrm{bcm} / \mathrm{yr}$ to the export potential of the region from the second half of the 2020s, if the Aphrodite field is developed.

Turning this export potential into a reality requires export infrastructure to take the gas produced in the individual countries to regional markets and other markets farther afield be they in the EU or Asia. As discussed below, however, with the exception of Egypt and Israel, the countries in the region lack gas export infrastructure.

In view of the size of its domestic gas market and the existence of export infrastructure, Egypt is seen as both a market and as an export route for East Mediterranean gas. Egypt has a well-established gas export infrastructure, both pipeline and LNG. The Arab Gas Pipeline (AGP), with an annual capacity of $10 \mathrm{bcm}$, connects Egypt to Syria via Jordan (see Figure 6). ${ }^{27}$ Natural gas exports by pipeline commenced in 2003 through the AGP to Jordan. Egyptian gas via the AGP reached Syria in 2008 and Lebanon in 2009. The pipeline has, however, been idle since 2011 when its feeder pipelines were damaged during the unrest in Egypt. The section to Jordan became operational again in 2019 .

The East Mediterranean Gas pipeline (EMG), an offshore pipeline with an annual capacity of $7 \mathrm{bcm}$ connecting the Israeli transmission system in the Ashkelon area with the Egyptian transmission system in El-Arish, was originally built to transport

27 The pipeline was built in four phases. The first phase (Arish-Aqaba section) was completed in 2003, the second phase (Aqaba to Rehab) in 2005, the third phase (Rehab to Jabber) in 2007, and the last phase (the Jordan-Syria borders to Homs in the North of Syria) in 2008. 
Egyptian gas to Israel (see Figure 6). By reversing its flow, the EMG now serves as a transport route for gas from the Tamar and Leviathan offshore fields in Israel to Egypt. In 2019, the partners in the Tamar and Leviathan fields concluded a contract with the privately-held Egyptian firm Dolphinus Holdings Ltd for the sale of $85 \mathrm{bcm}$ of gas between 2020 and 2034. The imported gas is partly to meet the needs of the domestic Egyptian market and partly for re-export, possibly as LNG. ${ }^{28}$ Leviathan field gas started flowing to Egypt through EGM at the beginning of 2020. Exports from the Tamar field to Egypt are expected to commence in the second half of 2020. Gas exports are expected to reach $7 \mathrm{bcm}$ per year at a plateau level. ${ }^{29}$

Leviathan and Tamar partners have also signed contracts with companies in Jordan to export approximately $7 \mathrm{bcm}$ of gas annually via the two above-mentioned pipelines. Exports from the Tamar field to the Arab Potash Company and the Jordan Bromine Company started in 2017. Tamar partners are committed to deliver a total of $1.8 \mathrm{bcm}$ of gas to those companies over a period of 15 years. In January 2020, gas from the Leviathan field also started to flow to Jordan pursuant to an agreement the Leviathan partners signed in 2016 with the Jordanian National Electric Power Company for the supply of $45 \mathrm{bcm}$ of gas over a period of 15 years. ${ }^{30}$ There are also on-going discussions for the export of up to $1 \mathrm{bcm} / \mathrm{yr}$ of gas by a pipeline from the Negev to Gaza, which could feed power plants. ${ }^{31}$

In addition, Egypt has two LNG liquefaction plants, Idku and Damietta, whose combined annual capacity is $19 \mathrm{bcm}$ (see Figure 6). The countries in the region, in particular Cyprus and Israel consider these two plants their key to the export markets of Europe and Asia. However, as the discussion in section 5 reveals the commercial challenges facing this route in the short, medium and long term are considerable. In fact, at the time of writing this article the two LNG facilities are idle given the low world LNG prices and the excess gas supply from the Zohr field.

Theoretically the best option for exporting the gas within the region, as well as from the region, to Turkey would be to connect the gas fields in the East Mediterranean to the AGP. This $10 \mathrm{bcm} / \mathrm{yr}$ capacity pipeline could also take in gas from Lebanon and Syria if gas were found there. However, the current conflict in Syria and political disputes in the region make this existing export route currently unviable. Accordingly, the export routes discussed below are being explored instead (see Figure 6).

Since Cyprus has no gas export infrastructure and the discoveries to date are not considered sufficient to make the building of an LNG plant at Vassilikos commercially

28 Delek Drilling, 'Engagement in binding agreements for the export of natural gas to Egypt' (2 October 2019) www.delekdrilling.com/sites/default/files/media/document/field_rp_pdf/Dolphinus\%20report\% 202.10.2019.pdf accessed 25 August 2020.

29 From the Tamar field: approximately $1 \mathrm{bcm} / \mathrm{yr}$ beginning on 30 June 2020 and ending on 30 June 2022, approximately $2 \mathrm{bcm} / \mathrm{yr}$ beginning on 1 July 2022 and ending on 31 December 2034. From the Leviathan field: approximately $2.1 \mathrm{~cm} / \mathrm{yr}$ beginning on 1 January 2020 and ending on 30 June 2020, approximately $3.6 \mathrm{bcm} / \mathrm{yr}$ in the period beginning on 1 July 2020 and ending on 30 June 2022, and finally approximately $4.7 \mathrm{bcm} / \mathrm{yr}$ in the period beginning on 1 July 2022 and ending on 31 December 2034; see ibid.

30 For more on the gas contracts with Jordanian customers see Delek Drilling, 'Tamar Gas Field' www. delekdrilling.com/natural-gas/gas-fields/tamar accessed 25 August 2020; Delek Drilling, 'Leviathan Gas Field' www.delekdrilling.com/natural-gas/gas-fields/leviathan accessed 25 August 2020.

31 Ahmad Melhem, 'Will Israel Go through with Plan to Develop Gaza Gas Field?' Al Monitor (31 January 2020) www.al-monitor.com/pulse/originals/2020/01/palestinian-authority-israel-import-gasgaza-field-power.html accessed 25 August 2020. 
viable, ${ }^{32}$ at present there is much discussion about building a sub-sea pipeline (known as the 'EastMed pipeline') from the Aphrodite field either to the EU or to Egypt.

The EastMed pipeline project aims to link Israel and Cyprus to Greece. After several joint declarations reaffirming the political support for the project over the years, Israel, Greece and RoC finally signed an inter-governmental agreement to build the $1900 \mathrm{~km}$ EastMed pipeline in January $2020 .^{33}$ This pipeline, which is included on the European Commission's Projects of Common Interest ${ }^{34}$ list, is expected to carry $10 \mathrm{bcm}$ of gas annually and cost US\$6-US\$7 billion to build. Another project, known as IGI Poseidon, aims to extend the EastMed pipeline from Greece to Italy. The final investment decision for the EastMed pipeline is expected sometime in 2022 and the pipeline's completion is envisaged for 2025. The key challenge facing this pipeline is that it needs to cross the EEZs of Turkey and Cyprus and that, as discussed in section 6, the maritime boundaries between Cyprus and Turkey and Turkey and Greece are not delimited. Moreover, to date, only Energean has formally shown an interest in supplying gas to the pipeline. ${ }^{35}$

The alternative export route for Cyprus gas is the $300 \mathrm{~km}$ pipeline project to export $8 \mathrm{bcm}$ of gas per year from Cyprus to Egypt to meet Egyptian domestic demand and/or for re-export via the Idku LNG plant in Egypt. This project has been under discussion since 2014. RoC and Egypt signed an inter-governmental agreement concerning the sub-sea pipeline project on 19 September $2018 .{ }^{36}$ This pipeline project is estimated to cost US\$1 billion and to be completed by $2025 .{ }^{37}$ However, no concrete actions have been reported as having been taken to realise this project to date.

In addition to the pipeline projects mentioned above, there have been several initiatives to build a gas pipeline and an electricity cable between the TRNC and Turkey, in parallel to the existing water pipeline. In November 2019, statements in support of these projects were made at the ministerial level in Turkey for the first time. According to Turkish government officials, the pipeline is intended to bring gas from Turkey to

32 On 26 June 2013, Nobel Energy, Delek Group and Avner signed a Memorandum of Understanding with RoC to build an LNG plant in Vassilikos. The intention was to build the plant by 2016 and start exporting gas by 2020; see Globes Correspondent, 'Delek, Noble Energy sign Cypriot LNG plan MOU' Globes (26 June 2013) https://en.globes.co.il/en/article-1000857277 accessed 25 August 2020.

33 Israeli Ministry of Energy, 'Press Release: The EastMed Gas Pipeline Accord has been signed at a Trilateral Summit between PM Netanyahu, Greek PM Kyriakos Mitsotakis and Cypriot Pres. Nicos Anastasiades' (2 January 2020) www.gov.il/en/departments/news/ng_021220 accessed 25 August 2020.

34 Regulation (EU) No 347/2013 of the European Parliament and of the Council of 17 April 2013 on Guidelines for Trans-European Energy Infrastructure and Repealing Decision No 1364/2006/EC and Amending Regulations (EC) No 713/2009, (EC) No 714/2009 and (EC) No 715/2009, [2013] OJ L115/39.

35 On 3 January 2020, DEPA (a majority Greek-state owned company) and Energean signed a letter of intent regarding the sale of $2 \mathrm{bcm}$ of gas per year from Energean's Karish and Tanin gas fields offshore Israel; see DEPA, 'Energean and DEPA agreement paves the way for commercial operation of Eastmed pipeline' (2 January 2020) www.depa.gr/energean-and-depa-agreement-paves-the-way-forcommercial-operation-of-eastmed-pipeline-athens-january-2nd-2020/?lang=en accessed 25 August 2020.

36 Cyprus Press and Information Office, 'Press Release: Remarks by the Minister of Energy, $\mathrm{Mr}$ Y. Lakkotrypis, at the signing of the agreement between Cyprus and Egypt for the submarine natural gas pipeline' (19 September 2019) www.pio.gov.cy/en/press-releases-article.html?id=3772\#flat accessed 25 August 2020.

37 Hend Soliman and Alessandro Scipione, 'Egypt and Cyprus Launch a New Gas Route' About Energy (30 July 2019) www.aboutenergy.com/en_IT/topics/Egypt-Cyprus-eng.shtml accessed 25 August 2020. 
the island. In the future the direction of the flow could be reversed and it could, should a solution to the Cyprus conflict be found, provide an export route for RoC's gas. ${ }^{38}$

Another possible export route for East Med gas is Turkey. Since the discoveries of the Tamar and Leviathan fields in Israel, several Turkish companies have shown interest in buying gas from Israel. Over the years discussions to build an $8 \mathrm{bcm}$ pipeline from the Leviathan field (possibly with a link to the Tamar field) to the south-eastern Mediterranean coast of Turkey, either directly or indirectly (via Cyprus), and possibly from there onwards to Europe have ebbed and flowed reflecting the continually changing nature of Turkey-Israel relations. For a while, the project had US government backing and was seen as a possible catalyst for resolving the Cyprus problem. ${ }^{39}$ However, with Turkey/ Israel and EU/Turkey relations currently at their lowest point in over a decade this project has now been completely shelved.

Exporting LNG via a dedicated floating liquefied natural gas (FLNG) facility has been considered in the past as a further alternative export route. However, due to the huge costs associated with the construction of an FLNG facility and the low LNG prices environment, this option is unlikely to be commercially viable.

In summary, unless new gas export infrastructure is built, it will be difficult for significant quantities of gas to be exported out of the region. Without access to markets outside the region the commercialisation of gas in the individual countries of the East Mediterranean will be difficult for reasons discussed in section 4. Building joint export infrastructure is an obvious example of the type of project that would benefit all countries in the region. However, this would require them to co-operate - something they have so far not been able to do. Ways to unlock this co-operation are explored in Section 7.

\section{Commercial challenges facing gas production in the region}

All the drilling, licensing and production activities described in section 2 might suggest that things bode well for the exploitation and commercialisation of gas reserves in the region. Companies generally carry out costly exploration and field development only if they expect to commercialise their discoveries by selling the gas produced to domestic and/or international markets. However, the current market realities and the expectations for the near future suggest otherwise. In particular, the Eastern Mediterranean faces the following four challenges.

First is the price challenge. The price of gas agreed in contracts for the export of gas from Israel's Tamar and Leviathan fields to Egypt and Jordan are linked to Brent oil prices and a floor price is set in the contracts. The cost of the gas is expected to be US\$4-5/MMBtu at the Leviathan well-head and the gas export price is reported to

38 Editorial, 'KKTC'den doğalgaz boru hattı açıklaması' CNNTurk (23 November 2019) www.cnnturk. com/ekonomi/kktcden-dogalgaz-boru-hatti-aciklamasi accessed 25 August 2020; İlhan Sağsen, 'Türkiye-KKTC doğal gaz boru hattı Doğu Akdeniz'de jeopolitik dengeleri değiștirecek' Anadolu Agency (24 December 2019) www.aa.com.tr/tr/analiz/turkiye-kktc-dogal-gaz-boru-hatti-doguakdenizde-jeopolitik-dengeleri-degistirecek/1682833 accessed 25 August 2020; Evie Andreou, 'Gas pipeline to connect the north with Turkey under discussion' Cyprus Mail (22 November 2019) https://cyprus-mail.com/2019/11/22/gas-pipeline-to-connect-the-north-with-turkey-under-discussion accessed 25 August 2020.

39 See further discussion in Section 5 below. 
be US\$6/MMBtu, assuming a Brent oil price in the range of US\$60-70 per barrel. ${ }^{40}$ With oil prices having more than halved by the end of May compared with what they were at the beginning of 2020 as a result of both supply and demand shocks, triggered by the Russia/Saudi price war and the coronavirus pandemic, many speculated that gas imported from Israel could be sold at a profit in Egypt going forward. However, with the oil prices having recovered (at the time of the publication of this article in September 2020) this now seems unlikely. The decision taken by the Egyptian government to further reduce gas prices for industrial use to US\$4.50/MMBtu in March 2020 in order to combat the coronavirus, and the expectation that it will announce a further reduction in gas prices in the near future, makes this scenario even more unlikely. ${ }^{41}$

The second challenge, related to the first, concerns the competitiveness of the region's gas at export destinations outside the region. When liquefaction and shipment costs are added to the cost of imported gas from Israel, the landing price of LNG from the Idku or Damietta LNG plants in Europe (perhaps even in Asia) is likely to be much higher than the price of gas imported from any other country in the world. In particular, it is likely to be much higher than Russian gas and significantly higher than the hub prices in Europe. ${ }^{42}$ Hub prices in Europe (eg, Title Transfer Facility Virtual Trading Point [TTF]) are forecast to stay below US\$4/MMBtu in the short term and to remain within the US\$4-8/MMBtu range in the longer term (2030). ${ }^{43}$ Although it is too early to assess the quantitative impact of the Russia/ Saudi oil price war and the coronavirus pandemic on the international gas markets, it is clear that oil and gas prices are under heavy pressure. Taking the glut in the world LNG markets into account as well, it is highly unlikely that importers of gas into Europe will be willing to pay a premium for Eastern Mediterranean gas that would enable Egypt to re-export Israeli gas at a profit just for the sake of supply security.

The third challenge concerns the risk of oversupply of gas as producers in the region may find themselves unable to find a market for their surplus gas. This has already happened in Egypt. The surge in domestic gas production, the tapering of domestic gas demand, and the very low LNG prices have forced Egypt to cap production in 2019 to avoid exporting LNG at discount prices. LNG exports from the Idku LNG plant in Egypt were stopped in mid-March 2020 (until the end of July when the next

40 Charles Ellinas, 'Challenges to Israel's gas exports' Cyprus Mail (15 September 2019) https://cyprusmail.com/2019/09/15/challenges-to-israels-gas-exports accessed 25 August 2020.

41 Editorial, 'Egypt reduces energy prices for industrial users during Covid-19' Offshore Technology (20 March 2020) www.offshore-technology.com/comment/egypt-covid-19 accessed 25 August 2020.

42 In Turkey, where gas import prices are believed to be higher compared to other countries in Europe, the gas import price from Russia is estimated at over US\$8/MMBtu in the first quarter of 2020 . This price is expected to decline to around US\$6 if the Brent oil price remains around US\$25-30/barrel, according to Energy IQ Weekly (No.384, 22 April 2020). This would make Turkey arguably the most attractive gas market for East Mediterranean gas. For a recent comparison of Russian gas with Hub prices see OIES, 'Quarterly Gas Review' (May 2020) www.oxfordenergy.org/publication-topic/quarterly-gasreview accessed 25 August 2020.

43 Rystad Energy, 'Press Release: "Global oil \& gas prices in 2020 set to fall short of earlier forecasts as coronavirus spreads" (27 February 2020) www.rystadenergy.com/newsevents/news/press-releases/ global-oil-gas-prices-in-2020-set-to-fall-short-of-earlier-forecasts-as-coronavirus-spreads accessed 25 August 2020. 
scheduled cargo is due) due to extremely low LNG prices. ${ }^{44}$ However, constraining domestic production capacity is unlikely to be a viable strategy for keeping the country's upstream sector attractive. Considering the fact that Egas pays US\$2.65/MMBtu for the bulk of onshore production and around US\$4-5/MMBtu for most offshore output $^{45}$ in the short term it could in fact be more profitable for Egypt to import LNG, whose spot price declined to US\$2/MMbtu in May. In addition, there is growing concern that the private Egyptian firm Dolphinus will not be able to take the full quantities of gas from the Tamar and Leviathan fields since Egypt has a surplus of gas. The sales contract with Dolphinus gives it an option to reduce, by up to 50 per cent, the contracted quantity of gas it offtakes in a year in which the average daily Brent price is lower than US\$50 per barrel. The Leviathan partners will likely, therefore, need to look to the Israeli domestic market for further gas sales deals. Although Israeli gas demand will continue to grow as coal-fired power plants switch to gas, the main problem is that the rapidly growing solar sector is eating into the potential market share of gas. Further, there is likely to be an oversupply of gas to Israel with the Greek company Energean Oil\&Gas slowly but steadily increasing its share of the Israeli gas market. The company's Karish field will supply approximately $5.6 \mathrm{bcm}$ per year to the domestic market once it starts producing in 2021 .

Furthermore, the main gas export market in the region, Jordan, may not require additional gas imports either, and particularly not the large quantities stipulated in the contracts signed with the Leviathan partners. In fact, the current oversupply of gas in Jordan is threatening key power generation start-ups. Jordan currently has three sources of gas supply - from Egypt and from Israel via pipelines and from Shell via LNG. In addition, Jordan has committed to buying 12 LNG cargos from Shell in $2020{ }^{46}$ This oversupply of gas, combined with the power generation capacity surplus, ${ }^{47}$ is likely to force the government to introduce radical energy policy measures, such as delaying or freezing renewable projects and paying independent power producers not to generate electricity. All of this points to a significant oversupply of gas in the region.

The fourth challenge facing the region concerns the availability of LNG export capacity in Egypt. It is a generally held view in the gas industry that the LNG facilities in Egypt are the export route for Israeli gas on account of Egypt not having enough indigenous gas to meet its domestic demand. This view is based on Wood Mackenzie's projections for the gas supply-demand balance. ${ }^{48}$ According to Wood Mackenzie, gas production in Egypt will peak at around $80 \mathrm{bcm}$ in 2025 , after which it will remain below its domestic demand. On this analysis, Egypt will remain reliant on imports to avoid LNG facilities lying idle. In contrast, according to OME, Egyptian gas production will not peak until the mid-2030s. Should OME's projection prove correct, there will be

44 Peter Stevenson, 'Egypt Halts LNG Exports as Eni \& Shell Bear the Brunt of Gas Surplus' (2020) 63 (15) MEES www.mees.com/2020/4/10/oil-gas/egypt-halts-lng-exports-as-eni-shell-bear-the-brunt-ofgas-surplus/f1f6f100-7b33-11ea-98a1-d7a0ef9df7e1 accessed 25 August 2020.

45 MEES, vol. 63, no. 15, 10 April 2020.

46 MEES, vol. 62, no. 44, 1 November 2019.

47 This surplus is caused by a boom in electricity production from renewables after three tenders (two in 2015 and one in 2018), the oil shale-to-power project which is expected to come on line in mid-2020 and gas-fired power projects.

48 Delek Group, 'Investor Presentation' (November 2019) https://ir.delek-group.com/static-files/ 691d5197-6315-4313-ab09-c0189da51a75 accessed 25 August 2020. 
no capacity available for Israeli gas in Egypt's LNG plants until the mid-2030s. ${ }^{49}$ If so, Egypt will not be a route for Israeli gas until after the mid-2030s. Cyprus gas looks to face the same challenges as Israeli gas since Egypt is seen as its main regional market, and the LNG facilities in Egypt a key means of accessing international markets further afield.

Given these commercial challenges, domestic markets and the markets in the immediate neighbourhood like Jordan do not provide companies operating in the Eastern Mediterranean with sufficient long-term security of demand to make the significant capital investment needed to develop the gas resources in the region. This, in turn, means that unless a viable export route is found to take the gas outside the region (see discussion in section 3) the future of gas development in the region remains uncertain.

Turkey, as the fifth largest gas market in the Euro-Mediterranean region, is arguably the best outlet for the gas produced in the region for the following three reasons: first, because virtually its entire gas demand is covered by imports; second, because a large proportion of Turkey's long-term gas purchase contracts, totalling around $20 \mathrm{bcm} / \mathrm{yr}$, is due to expire before 2025; and, third, because the gas prices set by Boru Hatlari Ile Ptrol Tasima Anonim Sirketi (BOTAS), a state-owned company, are much higher than those in Europe, therefore enabling the gas producers from the region to secure higher prices than in Europe. However, the legal and geopolitical challenges discussed in the following section stand in the way.

\section{Maritime boundary disputes as one of the key impediments to exploitation and transportation of gas}

The legal, geopolitical and security challenges to the exploitation and exportation of gas in the Eastern Mediterranean region are many. The fact that the majority of maritime boundaries between the countries in the region are not demarcated is probably one of the two key impediments to gas exploration and production in the region. ${ }^{50}$ At present, there are no agreements delimiting the maritime boundary between Greece and Turkey, the RoC and Turkey, the RoC and Syria, Israel and Lebanon or Israel and Palestine, and the agreements that have been signed (see discussion below) are contested by neighbouring countries.

All countries in the region have deposited their maritime claims regarding the territorial seas (TS), contiguous zone, EEZ and the CS with the United Nations (UN). ${ }^{51}$

49 Mediterranean Energy Perspectives (OME 2018).

50 The other is the Cyprus problem. For a historical overview of the Cyprus problem, see Harry Tzimitras and Mete Hatay, The Need for Realism: Solving the Cyprus problem through linkage politics (Center on the United States and Europe at Brookings 2016) www.brookings.edu/wp-content/uploads/2016/10/ turkey_20161005_cyprus_problem.pdf accessed 25 August 2020; see International Crisis Group, 'Divided Cyprus: Coming to Terms on an Imperfect Reality' (March 2014) www.crisisgroup.org/ europe-central-asia/western-europemediterranean/cyprus/divided-cyprus-coming-terms-imperfectreality accessed 25 August 2020; for a discussion of the current challenges to resolving the Cyprus problem, see James Ker-Lindsay, The Cyprus Problem in an Era of Uncertainty: Establishing a Culture of Engagement (PCC Report 5/2019, Prio 2019) https://cyprus.prio.org/Publications/ Publication/?x=4292 accessed 25 August 2020.

51 Table of claims to maritime jurisdiction (as of 15 July 2011), United Nations, Division for Ocean Affairs and the Law of the Sea www.un.org/Depts/los/LEGISLATIONANDTREATIES/PDFFILES/ table_summary_of_claims.pdf accessed 25 August 2020. 
The RoC and Egypt were the first countries in the region to sign an agreement delimiting their EEZs. ${ }^{52}$ They did so on 17 February 2003. ${ }^{53}$ Then in 2007 the RoC signed an agreement with Lebanon. ${ }^{54}$ However, this agreement was never ratified by the Lebanese government and hence is not in force. ${ }^{55}$ In December 2010 the RoC signed an EEZ delimitation agreement with Israel. In response, in September 2011 Turkey signed an EEZ delimitation agreement with the internationally unrecognised TRNC. In 2014 Egypt and RoC entered into a Framework Agreement concerning the Development of Cross-Median Line Hydrocarbons Resources. ${ }^{56}$ In December 2019 Turkey signed an EEZ delimitation agreement with Libya. On 6 August 2020 Egypt and Greece entered into an EEZ agreement. ${ }^{57}$

All of the above-mentioned maritime delimitation agreements are contested by the other countries in the region. In particular, Turkey and Turkish Cypriots contest the RoC's right to sign maritime delimitation agreements with other countries in the region on account of it not representing the interest of the Turkish Cypriots. ${ }^{58}$ In addition, Turkey disputes the maritime boundary agreed between RoC and Egypt because of its own CS claim extending west of Cyprus to the Greek island of Rhodes (Rodos). Lebanon objects to the RoC's delimitation agreement with Israel because the agreement takes as the starting point of Israeli/RoC's EEZ demarcation point 1 of the Cyprus/Lebanon EEZs. Lebanon maintains that point 1 is not the terminal point of demarcation between the Cyprus and the Lebanese EEZs and that point 1 is 11 nautical miles north of the equidistant point between the Israeli, Lebanese and RoC

52 It could be said that the first maritime delimitation agreement in the region was Annex A to the Treaty concerning the Establishment of the Republic of Cyprus dated 19 August 1960, which delimited the land boundaries of the two sovereign base areas, which remain under UK jurisdiction, and prohibited RoC from claiming the waters lying between the land boundaries as part of its TS. The terms of Annex $\mathrm{A}$ are available at www.un.org/Depts/los/LEGISLATIONANDTREATIES/PDFFILES/TREATIES/ GBR-CYP1960A.PDF accessed 25 August 2020. It is not clear whether UK has claimed an EEZ in relation to the two sovereign bases under its jurisdiction.

53 Agreement between the Republic of Cyprus and the Arab Republic of Egypt on the Delimitation of the Exclusive Economic Zone (17 February 2003). www.un.org/Depts/los/LEGISLATIONAND TREATIES/PDFFILES/TREATIES/EGY-CYP2003EZ.pdf accessed 25 August 2020.

54 Agreement between the Government of the Republic of Lebanon and the Government of the Republic of Cyprus on the Delimitation of the Exclusive Economic Zone (17 January 2007) https://drive.google. $\mathrm{com} /$ file/d/1br1zsCq HT3cwQZXR6IiN45vTmM7rFUd/view? usp=sharing accessed 25 August 2020.

55 See (n 54) of which Article 5 expressly provides that it will only enter into force upon the exchange of instruments of ratification. Under international law and in particular, Articles 14 and 18 of the Vienna Convention on the Law of Treaties, which are considered to form part of CIL, the act of signing an agreement does not establish the consent to be bound nor does it create an obligation to ratify an agreement if the agreement makes clear that the signing of the agreement is conditional upon ratification; Vienna Convention on the Law of Treaties (23 May 1969) https://legal.un.org/ilc/texts/instruments/ english/conventions/1_1_1969.pdf accessed 25 August 2020.

56 The agreement was signed on 27 January 2012 and entered into force in 2014. The text of the agreement can be found at www.energybilaterals.org/agreements/570 accessed 25 August 2020.

57 The copy of the EEZ agreement has not yet been made public; Editorial, 'Egypt and Greece Sign Agreement on Exclusive Economic Zone' Reuters (6 August 2020) https://www.reuters.com/article/ us-egypt-greece/egypt-and-greece-sign-agreement-on-exclusive-economic-zone-idUSKCN252216 accessed 25 August 2020.

58 Law 46 in Attachment 11 of the Comprehensive Settlement of the Cyprus problem of 31 March 2004 (known as the 'Annan Plan') accorded the 'federal state' the power to delimit the maritime zones. See www.hri.org/docs/annan/Annan_Plan_April2004.pdf accessed 25 August 2020. The Greek Cypriots rejected the Annan Plan in April 2004. All attempts since then to resolve the problem have been unsuccessful. 
EEZs. ${ }^{59}$ Greece and the RoC object to the agreement between Turkey and TRNC as well as to the most recent agreement between Turkey and Libya. Since the latter agreement also overlaps with Egypt's EEZ claims, Egypt has also noted its objections thereto to the UN. Turkey has objected to the EEZ agreement signed between Greece and Egypt on 6 August 2020, as further discussed in section 6 (see Figure 10).

To understand some of the challenges faced by the exploration and export of gas in the East Mediterranean, the overlapping maritime boundary claims between (1) Israel and Lebanon and (2) Turkey, RoC, TRNC and Greece, as they concern Cyprus, are discussed below. The overlapping maritime boundary claims between the other countries in the region will not be discussed in this article.

\subsection{The overlapping maritime boundary claims between Israel and Lebanon}

The area of the overlapping territorial seas and EEZ claims between Lebanon and Israel is about $850 \mathrm{~km}^{2}$ (see Figure 7).

The countries have been technically at war since 1948. The discovery of the Tamar field offshore Israel in 2009 triggered a maritime boundary dispute, thereby adding further complexity to already fraught relations. Tensions were increased further in 2017 when the Lebanese government conducted bidding rounds for blocks 8, 9 and 10, parts of which fall within the disputed area (see Figure 7). To minimise the risk of direct confrontation between the two countries, no exploration has been conducted in these blocks, although the part of block 9 which Total, Eni and Novatek intend to explore seems to be well within the EEZ of Lebanon and at least $25 \mathrm{~km}$ from the overlapping area. In Israel, however, gas exploration activities have been conducted in the Karish and Tanin fields, a few miles from the disputed area. In response to the drilling in those fields Lebanon deposited a letter of protest with the UN on 26 January 2018. In this letter, Lebanon underlined its readiness to take measures against any attempt by Energean Oil and Gas to directionally drill in these blocks and exploit gas on the Lebanese seabed. ${ }^{60}$ Over the years, both Lebanon and Israel have threatened to use force against each other to protect their claims.

So far, attempts to resolve the dispute between the two countries have failed. ${ }^{61}$ Direct negotiations between the representatives of the governments of the two

59 In accordance with the principles of CIL on the delimitation of maritime boundaries, as set out in Article 74(1) of UNCLOS, the Cyprus/Lebanese EEZ agreement did not plot two northern points beyond point 1 in order not to prejudge the EEZ delimitation with Israel. According to the report of the United Nations Development Programme, taking point 1 of the Cyprus/Lebanon EEZ delimitation as the starting point of the Israeli/Cyprus delimitation is 'a violation of article 18 of the Vienna Convention on the Law of Treaties concerning the obligation not to defeat the object and purpose of a treaty prior to its entry into force' - that is, the Cyprus/Lebanese EEZ delimitation agreement. See Vida Hamd and others, The Maritime Boundaries and Natural Resources of the Republic of Lebanon (Common Space Initiative, 2014), 36. www.undp.org/content/dam/lebanon/docs/Governance/Publications/Legal $\% 20$ section\%201-6.pdf accessed 25 August 2020.

60 Communication from the Permanent Mission of Lebanon to the United Nations Addressed to the Office of the Secretary-General of the United Nations (26 January 2018). www.un.org/depts/los/ LEGISLATIONANDTREATIES/PDFFILES/communications/2018_01_26_lbn.pdf accessed 25 August 2020.

61 A detailed account of the conflicting claims, the international law on delimitation and the steps taken to date to resolve the dispute between the two countries is set out in Hamd (n 59). 


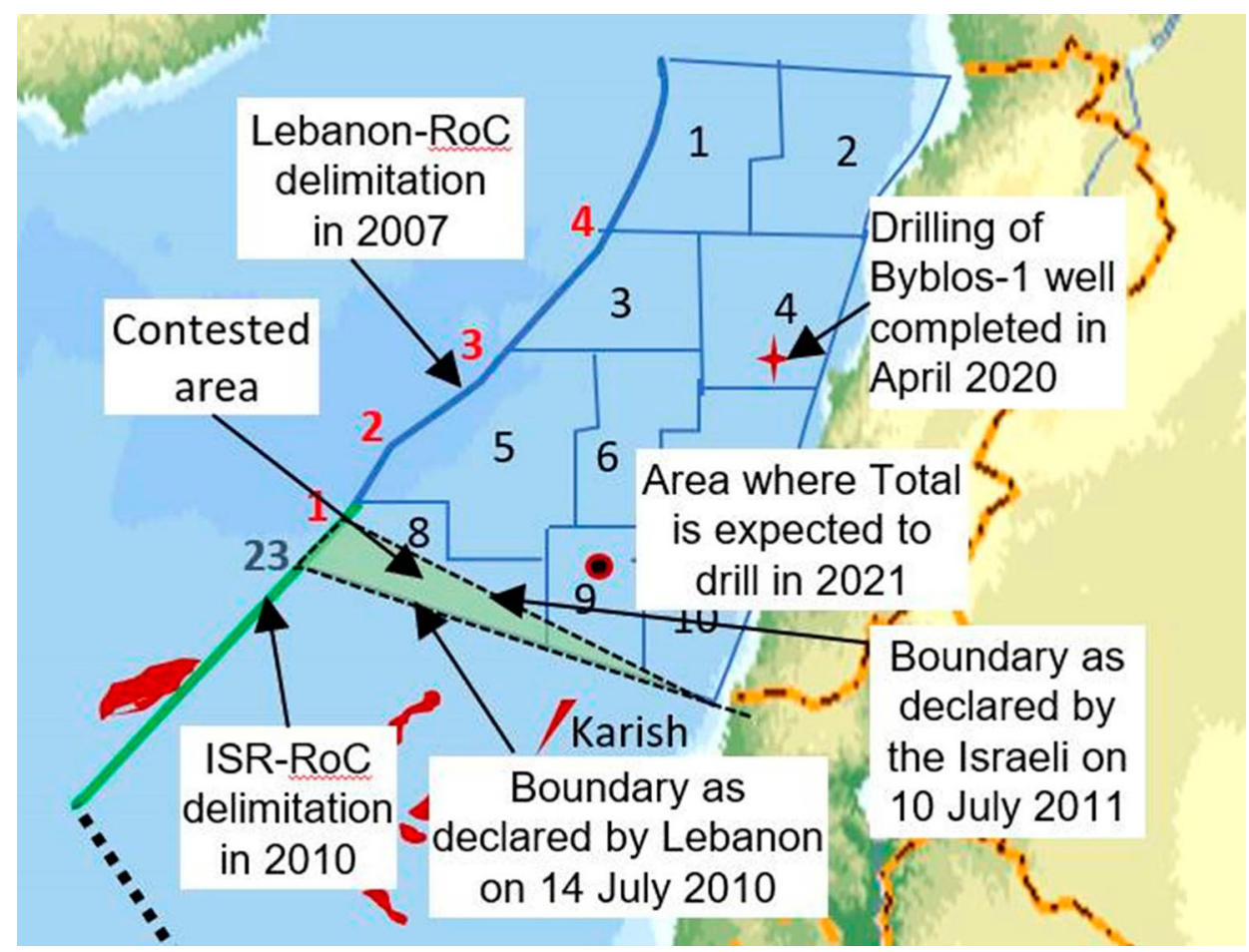

Figure 7. Israel-Lebanon maritime boundary dispute.

Source: Authors' own elaboration.

countries are not possible since the two countries are still technically at war. In 2012, in an attempt to mediate between the two countries, the USA proposed a demarcation of the border which recognised $500 \mathrm{~km}^{2}$ of the disputed maritime area as belonging to Lebanon, and proposed that Lebanon start gas exploration in this part of the area pursuant to a US guarantee that the dispute over the rest of the border would be resolved. However, neither Lebanon nor Israel responded to its proposal. In 2014, the US put forward another proposal to resolve the dispute. It proposed that a maritime separation line be drawn and for exploration in the disputed area by either country to be subject to the agreement of the other. The proposal also seemed to have envisaged the possibility of a unitisation framework agreement being agreed between the countries, which would have allowed joint exploitation and development by private companies of the area. However, neither country endorsed the proposal. Attempts to get the UN Secretary General, the UN Interim Force in Lebanon or the UN Special Coordinator for Lebanon to step in and resolve the dispute have also not been successful.

\subsection{The overlapping maritime boundary claims between Turkey, the RoC and Greece}

The overlapping maritime claims between Turkey, the RoC and Greece are even more challenging to resolve as they are further complicated by the so called 'Cyprus 


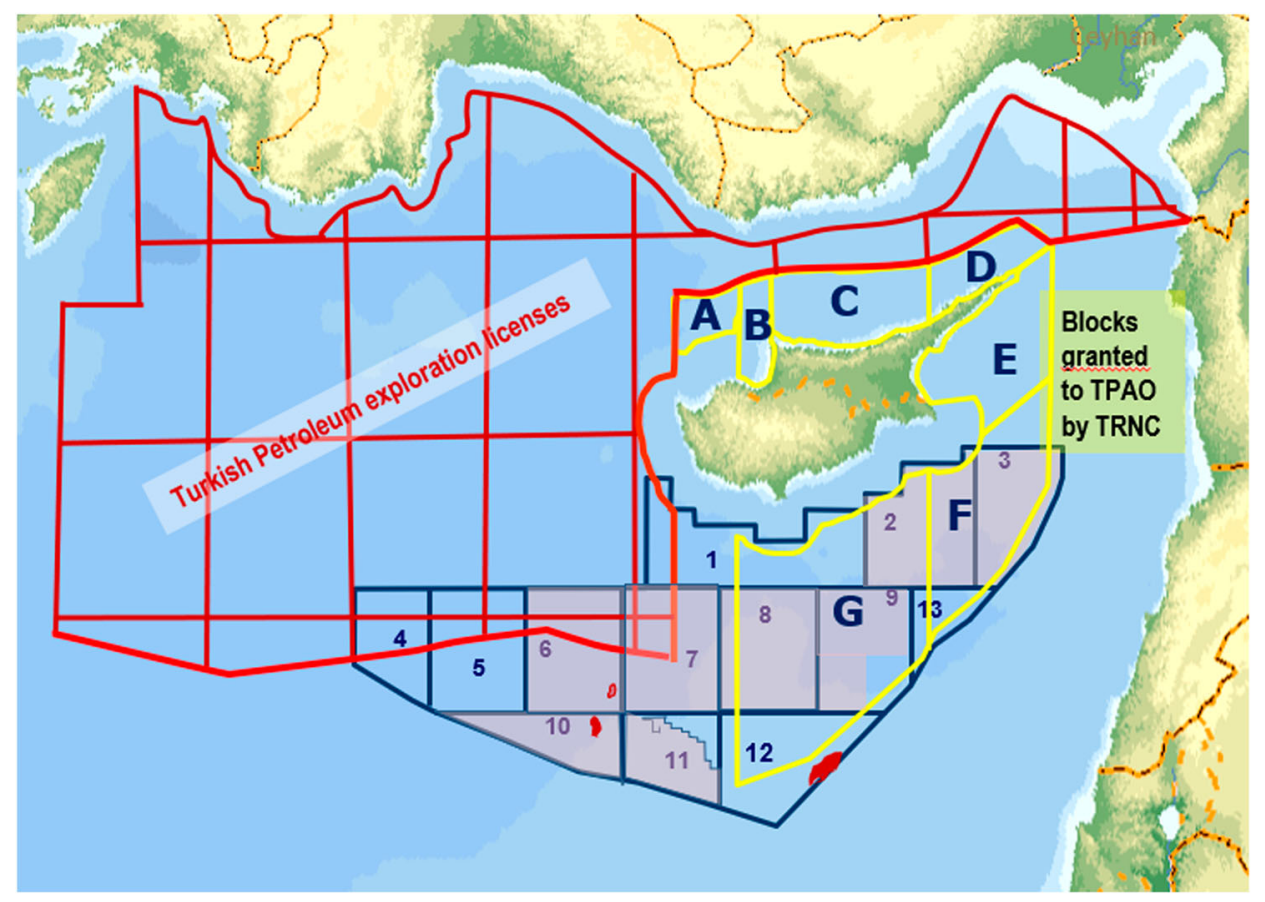

Figure 8. exploration activities and overlapping exploration blocks around Cyprus.

Source: Sohbet Karbuz.

problem, ${ }^{62}$ The island of Cyprus has been de facto partitioned since 1974 between the self-declared TRNC in the north of the island, where Turkish armed forces are stationed, and the remainder of the island which is under the control of the RoC. ${ }^{63}$ Due to the conflict, Turkey does not recognise the RoC nor, consequently, its EEZ. Moreover, Turkey maintains that the RoC government does not represent the Turkish Cypriot population and that its awarding of exploration blocks in its EEZs to international energy companies disregards the Turkish Cypriots' legitimate right to share any revenue from such exploration.

As shown in Figure 8, Turkey's EEZ claims, as registered with the UN, extend to the west of the island of Cyprus and overlap with those of the RoC. Turkey has objected to drilling in RoC's blocks 1, 4, 5, 6 and 7.

As noted in section 2, 2016 marked a new point of departure in the maritime boundary dispute between the $\mathrm{RoC}$ and Turkey. That year, the $\mathrm{RoC}$ granted a licence in respect of block 6, part of which is also claimed by Turkey. Also, in 2017 Turkey announced its intention to proceed to exploration drillings in areas delimited by the RoC. Within days of Eni announcing its discovery of gas (the

62 See (n 50) for historical overview of the problem as well as the current challenges and opportunities to resolve it.

63 See (n 2) for further information on the de jure and de facto status of the island of Cyprus. 
Calypso field $)^{64}$ in contested block 6 in February 2018, the Turkish navy blocked a drillship hired by Eni to drill for gas in block 3, to which the TRNC also lays claim. $^{65}$

Since 2019, TPAO has also been conducting geological research and hydrocarbons exploration activities in areas contested between Turkey and the RoC (parts of RoC's blocks 4, 5, 6 and 7) as well as in the TRNC's blocks F and G which overlap with RoC blocks 2, 3, 8, 9, 12 and 13. On 15 July 2019, in light of Turkey's continued drilling in disputed maritime areas, the EU Council suspended negotiations on the Comprehensive Air Transport Agreement and cancelled EU-Turkey high-level dialogue for the time being. It also endorsed the European Commission's proposal to reduce pre-accession assistance to Turkey for 2020 and invited the European Investment Bank to review its lending activities to Turkey. ${ }^{66}$

On 11 November 2019, and in view of TPAO's continued drilling in the disputed maritime areas, the EU Council adopted a framework of further measures which includes imposing sanctions on individuals and entities involved in drilling activities. These actions by the EU have so far not dissuaded TPAO. In May 2020, TPAO started drilling in a disputed area, the RoC's block 6. As discussed in section 6, further drilling activities were conducted by TPAO in contested maritime zones in July and August of 2020. At the time of writing this article, the tensions in the region remain very high. German Chancellor Angela Merkel's last-minute intervention on 22 July, which prevented a military conflict between Turkey and Greece, is evidence that the situation could easily escalate out of control (see section 6).

\section{Continuously shifting alliances and increased tensions in the region}

As discussed above, 2019 saw a significant rise in tensions in the region. Over the years, the substantial gas resources and the opportunities linked to their exploitation and transport have been changing the geopolitics and economics of the region, issues accentuated by the lack of maritime delimitation. The deterioration in relations between Turkey and Israel since 2008, between Turkey and Egypt since 2013 and between Turkey and the EU particularly since 2016 has played an important role in shifting alliances in the region. The Syrian conflict, the rise of the Islamic State of Iraq and Levant (ISIS) and the changing geo-strategic interests of the USA and Russia have made the region even more unstable.

The establishment of the East Med Gas Forum (EMGF), of which Egypt, Cyprus, Greece, Israel, Italy, Jordan and the Palestinian Authority are members, in January 2019 is an example of new alliances being formed. At the third ministerial meeting of the EMGF on 16 January 2020 a platform for East Mediterranean gas cooperation was set up with the encouragement of the USA and the EU. It is unclear how precisely the forum will go about creating a regional gas market, cutting infrastructure costs

64 Eni, 'Press Release: Eni Announces a Gas Discovery Offshore Cyprus' (8 February 2018) www.eni. com/en-IT/media/press-release/2018/02/eni-announces-a-gas-discovery-offshore-cyprus.html accessed 25 August 2020.

65 Sohbet Karbuz, 'EastMed Gas Developments' presentation at Turkey Energy Summit (Antalya, 7 October 2019).

66 European Council Conclusions of 20 June 2019, EUCO 9/19 (20 June 2019) www.consilium.europa. eu/media/39922/20-21-euco-final-conclusions-en.pdf accessed 25 August 2020. 
and offering competitive prices, especially whilst Turkey, Lebanon and Syria are not members. More may perhaps become clear after their next meeting, which is due to take place in the second half of 2020.

In response to being excluded from the EMGF, Turkey negotiated political, energy and security agreements with Libya in late 2019, the centrepiece of which is an agreement delimiting the EEZs of the two countries. As the maps in Figure 9 show, these EEZs overlap significantly with the EEZs claimed by Greece and Egypt. ${ }^{67}$

With the adoption of the Eastern Mediterranean Security and Energy Partnership Act in late December 2019, the USA has weighed in on the side of Cyprus and in favour of the EastMed Pipeline. ${ }^{68}$

Tensions threatened to trigger a military confrontation on 22 July 2020 when German Chancellor Merkel was reported to have prevented a naval and air confrontation between Turkey and Greece. The latter was triggered after Turkey sent a gas exploration vessel to drill near the Greek island of Kastellorizo, in an area of the Mediterranean Sea claimed by both. ${ }^{69}$

After Egypt and Greece signed an agreement, on 6 August 2020, delimiting their EEZs tensions increased even further. ${ }^{70}$ As the map in Figure 10 shows, their EEZs significantly overlap with the EEZs claimed by Turkey. In response Turkey sent a seismic research vessel, escorted by a warship, into the disputed waters a few days later (see Figure 10). In response to this, Greece placed its military on alert and France announced that it would increase its military presence in the East Mediterranean. With tensions so heightened it may take little for matters to spiral out of control. $^{71}$

\section{International law as a possible way forward}

As discussed above, the exploitation and export of gas in the region face numerous commercial, technical, legal and geopolitical challenges. Even if the four commercial challenges discussed in section 4 are overcome in the medium term, the legal and geopolitical challenges present important constraints on the exploitation and export of gas in the region. As discussed in section 5, the fact that the maritime boundaries between many of the countries in the region are not demarcated is a key impediment, which now threatens - as discussed in section 6 - the peace and security in the region.

67 H. E. Ambassador Çağatay Erciyes, 'Outstanding Issues in the Eastern Mediterranean and the Aegean Sea: Turkey’s Views and Policies’ presentation (13 February 2020) www.mfa.gov.tr/site_media/html/ Outstanding-Issues-in-the-Eastern-Mediterranean-and-the-Aegean-Sea-Turkey-s-Views-and-Policies. pdf accessed 25 August 2020.

68 Todd Prince, 'Congress Passes More Legislation Aimed At Curbing Russia's Energy Grip On Europe' Radio Free Europe (21 December 2019) www.rferl.org/a/congress-passes-more-legislation-aimed-atcurbing-russia-s-energy-grip-on-europe/30337217.html accessed 25 August 2020.

69 Editorial, 'Merkel Stoppt Militärkonflikt Zwischen Türken und Griechen' Bild (22 July 2020) https:// www.bild.de/bild-plus/politik/ausland/politik-ausland/tuerkei-gegen-griechenland-merkel-stopptmilitaerkonflikt-72012138,view=conversiontologin.bild.html accessed 25 August 2020.

70 See $\mathrm{n} 57$.

71 Editorial, 'With Oruc Reis, Turkey is breaking up the blockade of Greece - Greek Cypriot administration -Egypt in its south' Anadolu Agency (11 August 2020) www.aa.com.tr/en/info/infographic/ 19739 accessed 25 August 2020. 


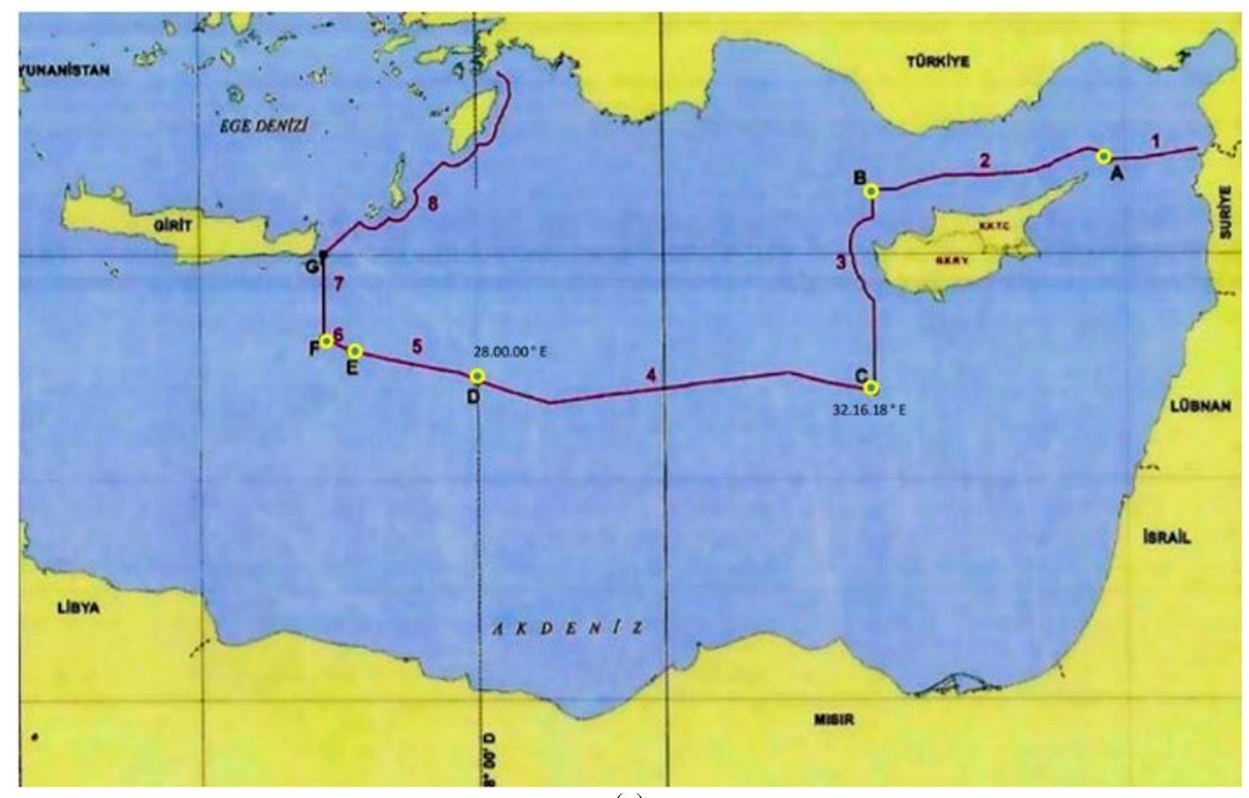

(a)

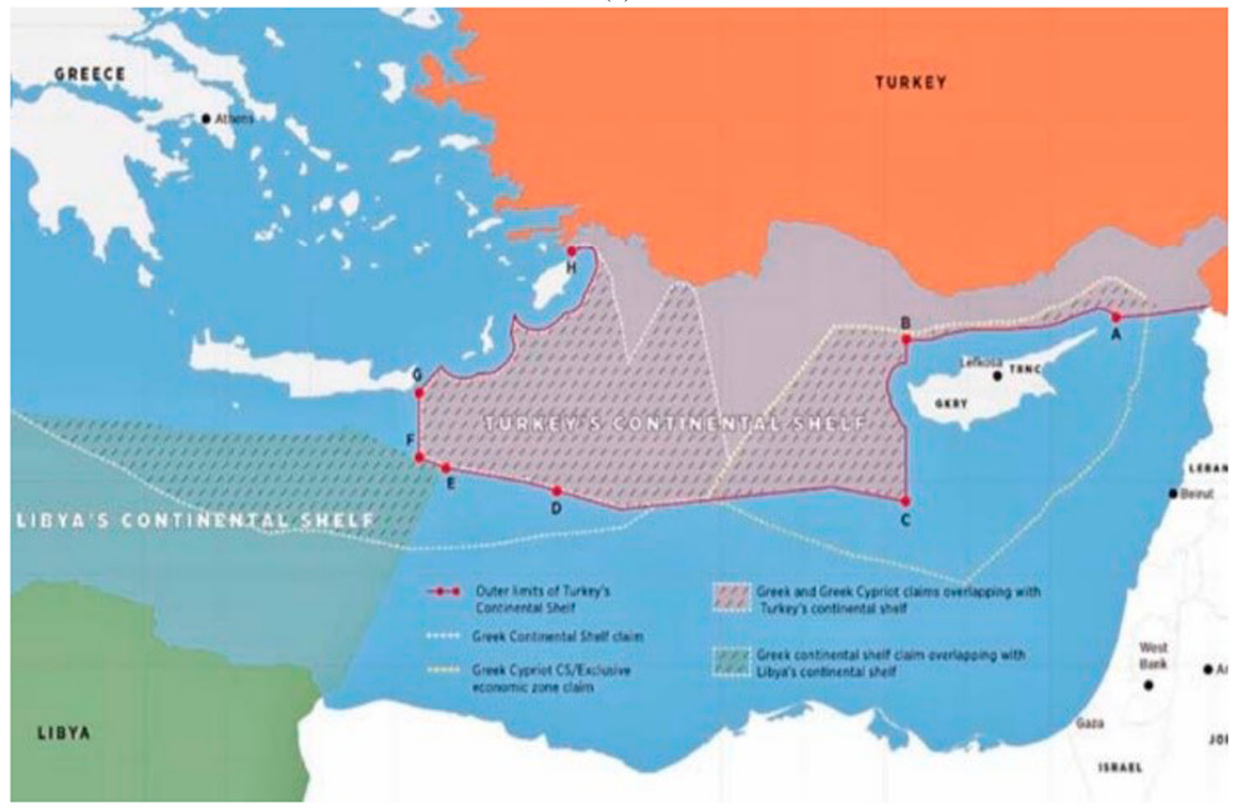

(b)

Figure 9. Turkey's exclusive economic zone agreement with Libya and overlapping continental shelf/exclusive economic zone claims. Reproduced by kind permission of the Ministry of Foreign Affairs of the Republic of Turkey.

Source: Cagatay Erciyes, Outstanding issues in the Eastern Mediterranean and the Aegean Sea: Turkey's views and policies, 13 February 2020.

This section therefore discusses the international law rules concerning (1) the exploration and exploitation of offshore gas and (2) maritime delimitation and disputes relating to them, to explore ways in which international law may be invoked to overcome these challenges. 


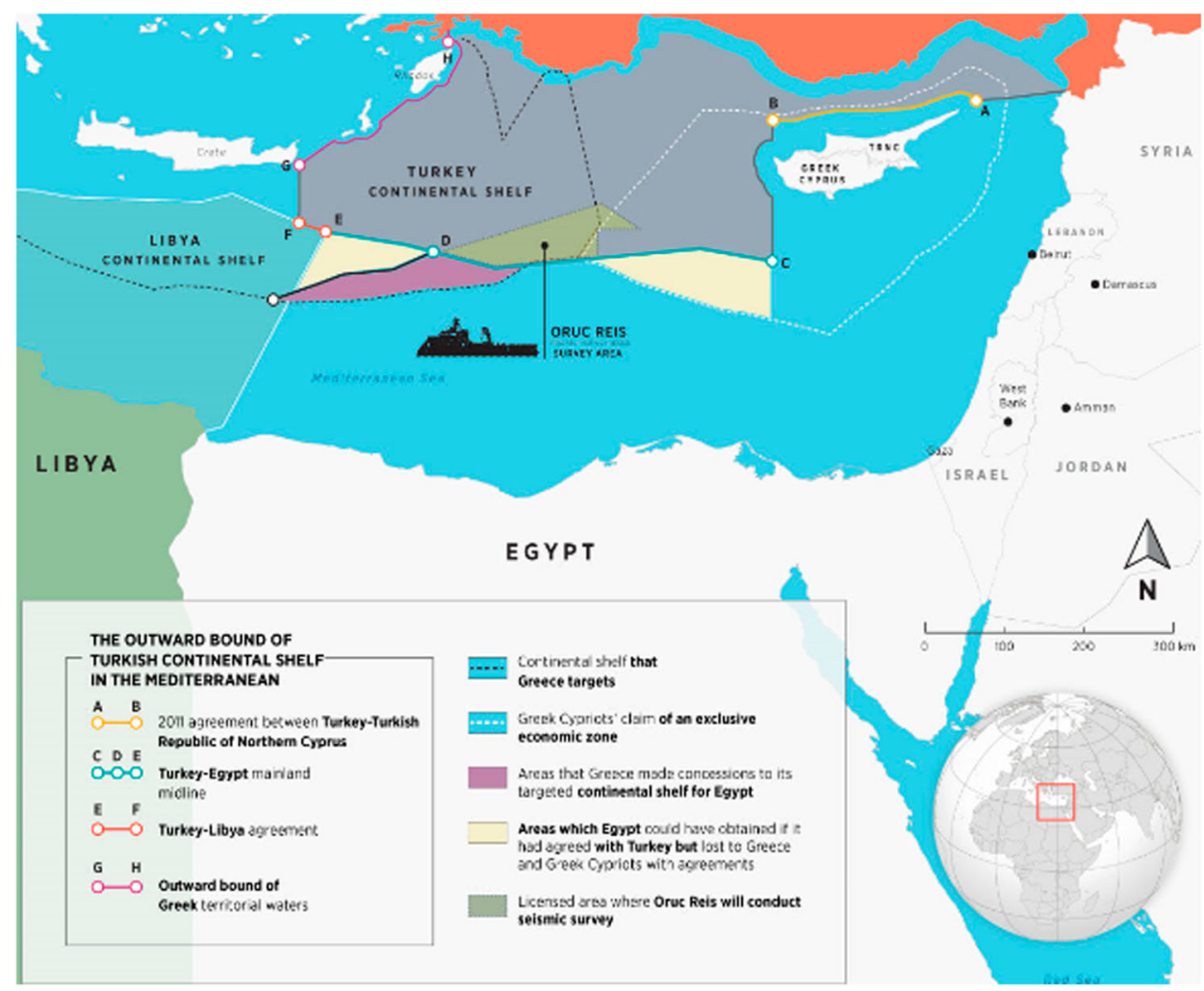

Figure 10. the overlapping exclusive economic zones between Greece, Turkey, the Republic of Cyprus, Egypt and Libya. Reproduced by kind permission of Anadolu Agency.

Source: Anadolu Agency.

The general principles of international law concerning the exploration and exploitation of gas as well as delimitation of maritime zones are set out in the relevant provisions of the 1982 United Nations Law of the Sea Convention (UNCLOS). ${ }^{72}$

For the reasons discussed below, the rules on the exploration and exploitation of gas in the TS, CS and EEZ as well as the maritime delimitation of these maritime zones as set out in UNCLOS are considered reflective of CIL. ${ }^{73}$ In other words, even though Israel, Syria, Palestine and Turkey are not party to UNCLOS they are in principle bound by these rules and consequently, any breach thereof could amount to a breach of CIL. ${ }^{74}$ In this regard it should, however, be noted that Turkey has persistently objected to being bound by UNCLOS provisions concerning the TS and islands to the extent that such rules form part of CIL. In accordance with principles of CIL,

7210 December 1982, 1833 UNTS; for an overview of these rules see James Crawford, Brownlie's Principles of Public International Law ( $9^{\text {th }}$ edn, OUP 2012) ch 12.

73 Brownlie (n 72); The Preamble of the Cyprus/Israel EEZ delimitation agreements expressly recalls the provisions of UNCLOS. Given that Israel is not a party to UNCLOS, this reference thereto denotes its acceptance that, at the very least, its provisions concerning the delimitation of the EEZ form part of CIL which it is obliged to comply with.

74 See (n 73). 
states that have established a persistent objection to principles of CIL are not bound by such principles.

\subsection{Rules on the exploration and exploitation of offshore gas}

The nature and scope of the rights of a coastal state differ among the categories of maritime zones recognised under UNCLOS. Pursuant to Article 2 of UNCLOS, a state's 'sovereignty ... extends, beyond its land territory and internal waters, ... to an adjacent belt of sea, described as the territorial sea', extending at most 12NM from the baseline (usually meaning the low-water mark) of said state. ${ }^{75}$ In other words, a coastal state has complete sovereignty to explore, exploit and transport gas in the TS, provided of course that its TS claim does not overlap with that of an adjacent or opposite state. In the case of such overlapping claims, the rules on delimitation of the TS discussed in section 7.2 apply.

Pursuant to Articles 56(1)(a) and 77(1) and (2) of UNCLOS, coastal states have sovereign rights (as opposed to sovereignty) for, inter alia, the purposes of exploring, exploiting and drilling for gas (1) in the EEZ, which cannot extend farther than 200NM from the baseline, and (2) on the CS, which extends to the outer edge of the continental margin (up to $350 \mathrm{NM}$ ) or a distance of $200 \mathrm{NM}$ from the baseline. ${ }^{76}$ The exclusive nature of these rights is reaffirmed in Article 81 of UNCLOS as it provides that a coastal state has the exclusive right to 'authorise and regulate drilling on the continental shelf for all purposes'. ${ }^{77}$ As discussed in section 7.3, in the case of overlapping EEZ and CS claims states unable to reach an agreement are required to 'make every effort to enter into provisional arrangements of a practical nature' pending agreement on final delimitation.

Articles 68 and 79 of UNCLOS, which are also considered reflective of CIL, permit all states to lay submarine cables and pipelines on the CS and in the EEZ of coastal states. Such a right is subject only to the coastal states' right 'to take reasonable measures for the exploration of the continental shelf, the exploitation of its natural resources and the prevention, reduction and control of pollution from pipelines' as well as its rights to delineate the course of the pipeline and to 'establish conditions $\ldots$ for pipelines entering its territory or territorial sea' ${ }^{78}$

\subsection{Rules on delimitation of TS}

Delimitation of the TS between opposite or adjacent states is primarily governed by Article 15 of UNCLOS which is considered reflective of CIL. ${ }^{79}$ It provides that

where the coasts of two States are opposite or adjacent to each other, neither is entitled, failing agreement between them to the contrary, to extend its territorial sea beyond the

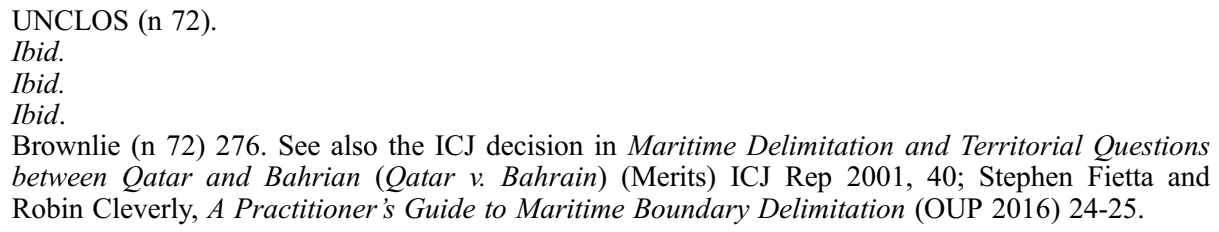
between Qatar and Bahrian (Qatar v. Bahrain) (Merits) ICJ Rep 2001, 40; Stephen Fietta and Robin Cleverly, A Practitioner's Guide to Maritime Boundary Delimitation (OUP 2016) 24-25. 
median line every point of which is equidistant from the nearest points on the baselines from which the breadth of the territorial seas of each of the two States is measured. The above provision does not apply, however, where it is necessary by reason of historic title or other special circumstances to delimit the territorial seas of the two States in a way which is at variance therewith. ${ }^{80}$

In other words, Article 15 gives primacy to delimitation being reached by agreement but provides that failing such agreement, the principle of equidistance should be used to delimit the TS. Article 15 further makes clear that departure from equidistance is only possible for historical reasons or in case of other special circumstances. 'Whether or not there is a formal presumption of equidistance in [TS] delimitation may be debated', but what is clear is that the International Court of Justice (ICJ) will first provisionally draw an equidistant line and then consider whether the line must be adjusted in light of the existence of special circumstances. ${ }^{81}$

\subsection{Rules on delimitation of the CS and EEZ}

Unlike in the case of delimitation of the TS, equidistance is not the principle of CIL for the delimitation of the CS and EEZ. Instead, Articles 83(1) and 74(1) of UNCLOS, which are considered reflective of CIL, provide that 'delimitation [ ... ] shall be effected by agreement $[\ldots]$ in order to achieve an equitable solution'. ${ }^{82}$ In other words, the guiding principle in the delimitation of CS and EEZ is achieving an equitable solution.

Equidistance is instead adopted as a general method of delimitation of the CS and EEZ. It can be replaced by another (the bisector method) in the event that the use of that other method is considered necessary to achieve an equitable solution. ICJ case law has repeatedly held that the following three step methodology for delimitation of the EEZ and CS represents a rule of CIL. ${ }^{83}$ Step 1 involves drawing the equidistant line between the two countries using baselines. Step 2 requires a consideration of whether there are factors or special circumstances due to which the equidistant line should be adjusted to reach an equitable solution. Step 3, known as the proportionality test, involves ensuring that the final demarcation line does not allocate significantly disproportionate areas between the countries compared to their respective coastal lengths.

It should be noted that equidistance was used by a number of states to demarcate EEZs in the East Mediterranean. In particular, it was the basis for delimitation in Cyprus' EEZ agreements with Egypt, Lebanon and Israel. ${ }^{84}$ It would seem that the position of Lebanon has changed and that it now favours the three-step methodology for delimitation in line with ICJ jurisprudence. As noted above, Turkey has persistently objected to being bound by provisions of UNCLOS concerning (1) the breadth and

80 United Nations Convention on the Law of the Sea (10 December 1982) www.un.org/depts/los/ convention_agreements/texts/unclos/unclos_e.pdf accessed 25 August 2020.

81 Brownlie ( $\overline{\mathrm{n}}$ 72) 284 and 285; see also ICJ decision in Maritime Delimitation in the Area between Greenland and Jan Mayen (Denmark v. Norway) ICJ Rep 1993, 38; Fietta and Cleverly (n 79) 24-25.

82 UNCLOS (n 72); see also Denmark v. Norway (n 81); see also Fietta and Cleverly (n 79) 24-25.

83 For a detailed account of the ICJ case law see Fietta and Cleverly (n 79).

84 For an account of the delimitation agreements entered into by Cyprus, see Nicholas A. Ioannides, 'Maritime Boundary Delimitation Agreements in the Eastern Mediterranean Sea' in Lawrence Martin and others (eds), Natural Resources and the Law of the Sea: Exploration, Allocation, Exploitation of Natural Resources in Areas under National Jurisdiction and Beyond (JurisNet 2017). 
delimitation of the TS (in particular, Article 3) and (2) islands (in particular, Article $121)$ to the extent they form part of CIL. It agrees, however, that equitable principles are the basis for delimitation of the $\mathrm{CS}^{85}$ Greece, on the other hand, although a party to UNCLOS, favours equidistance as a principle of delimitation between states with opposite coasts.

Importantly, unlike in the case of the TS, Articles 83(1) and 74(1) of UNCLOS do not prescribe the mechanism for delimitation of the CS or EEZ in the event that states are unable to reach agreement. Instead, Article 74(2) of UNCLOS requires the states to refer their delimitation dispute for resolution by one of the mechanisms set out in Part $\mathrm{XV}$ of UNCLOS.

Since in many instances in the East Mediterranean the EEZs of more than two countries overlap, it should be noted that bilateral delimitation agreements typically do not plot the complete maritime boundary between the two countries in question in order not to prejudge the boundary each of the countries has with the third state which is not party to the agreement. This approach reflects the general principle of international law of res inter alios acta, which provides that a contract cannot adversely affect the rights of a state which is not party to it.

\subsection{Obligations imposed on states in the case that agreement on delimitation is not reached}

As noted above, pursuant to Article 74(2), states party to UNCLOS unable to reach a delimitation agreement in respect of overlapping EEZs and CS are required to refer their dispute to dispute settlement procedures set out in Part XV of UNCLOS. Several different options are provided for under UNCLOS, including conciliation and arbitration. ${ }^{86}$ Since Lebanon and Cyprus are both parties to UNCLOS either has the right to (1) invite the other to resolve their delimitation disputes by conciliation under Article 284 or (2) unilaterally commence ad hoc arbitral proceedings to resolve such dispute pursuant to Annex VII of UNCLOS, invoking Article 287(3) thereof. ${ }^{87}$ Since Israel, Syria and Turkey are not parties to UNCLOS, delimitation disputes that concern them cannot be referred to the dispute resolution procedure provided thereunder. However, since all countries in the East Mediterranean (except Palestine) are members of the UN they are required, as per Articles 2(3) and 33 of the Charter of the UN, to 'settle their international disputes by peaceful means in such a manner that international peace and security, and justice, are not endangered' - means that include negotiations, mediation, conciliation, arbitration and judicial

85 For Turkey's position in respect of maritime delimitation in the Mediterranean Sea, see www.mfa.gov. tr/sub.en.mfa?22400a11-e3e5-4ed9-b1a3-d0ebc94ce9db accessed 25 August 2020.

86 To date, very few maritime delimitation disputes have successfully been resolved by conciliation. One example is the Iceland/Norway Continental Shelf Dispute Regarding Jay Mayen Island. Conciliation Commission on the Continental Shelf Area between Iceland and Jan Mayen: Report and Recommendations to the Governments of Iceland and Norway, decision of June 1981, Reports of International Arbitral Awards, vol. XXVII (United Nations 1981) 1-34.

87 In its judgment on the continental shelf case between Libya and Malta the International Court of Justice stated: 'It is in the Court's view incontestable that [ ... ] the institution of the exclusive economic zone [ ... ] is shown by the practice of States to have become a part of customary law'; see Case Concerning the Continental Shelf (Libya/Malta), ICJ Rep 1985 para 34. 
settlement. ${ }^{88}$ These provisions, however, do not oblige them to resolve their delimitation disputes.

Only Cyprus ${ }^{89}$ and Greece ${ }^{90}$ have accepted the compulsory jurisdiction of the ICJ. Israel, Lebanon, Syria, Egypt, ${ }^{91}$ Palestine and Turkey have not. ${ }^{92}$ Accordingly, except in the case of any delimitation disputes between Cyprus and Greece (of which there are none at present), special agreements referring delimitation disputes in the East Mediterranean region to third-party dispute resolution mechanisms would have to be entered into between the disputing countries. The most commonly adopted mechanisms opted for by states to resolve delimitation disputes are to refer the dispute to (1) the ICJ by special agreement pursuant to Article 36(1) of the Statute of the ICJ; or (2) ad hoc arbitration administered by the Permanent Court of Arbitration (PCA) in The Hague. Another option is to refer the dispute to arbitration by the International Tribunal on the Law of the Sea (ITLOS) ${ }^{93}$ ITLOS is a judicial body created especially for the purposes of adjudicating conflicts concerning the interpretation and application of UNCLOS. In deciding which of these options would be the most appropriate for resolving each of the delimitation disputes in the East Mediterranean region, a careful analysis of the pros and cons would need to be undertaken. The analysis should, inter alia, weigh the facts that (1) ITLOS has to date resolved three maritime boundary disputes and the PCA has administered five $;{ }^{94}$ (2) in an ad hoc arbitration administered by the

88 Palestine is not a member of the United Nations. However, since these provisions codify CIL is it also bound by these obligations; United Nations, Charter of the United Nations, 1 UNTS XVI (UN 1945); see Fietta and Cleverly (n 79), 122.

89 For the text of Cyprus' declaration recognising the jurisdiction of the ICJ dated 3 September 2002, International Court of Justice, Declarations recognizing the jurisdiction of the Court as Compulsory: Cyprus, www.icj-cij.org/en/declarations/cy accessed 25 August 2020.

90 For the text of Greece's declaration recognising the jurisdiction of the ICJ dated 14 January 2015, International Court of Justice, Declarations recognizing the jurisdiction of the Court as Compulsory: Greece, www.icj-cij.org/en/declarations/gr accessed 25 August 2020. In the declaration Greece has expressly carved out disputes over the 'breadth and limits of its territorial sea' and disputes in respect of which the ICJ's compulsory jurisdiction was deposited or ratified 'less than twelve months prior to the filing of the application bringing the dispute before the' court from ICJ's compulsory jurisdiction. Moreover, it recognises ICJ compulsory jurisdiction only in respect of other States who have accepted the same obligation - that is, on condition of reciprocity.

91 For the text of Egypt's declaration recognising the jurisdiction of the ICJ dated 22 July 1957, International Court of Justice, Declarations recognizing the jurisdiction of the Court as Compulsory: Turkey, www.icj-cij.org/en/declarations/eg accessed 25 August 2020. Egypt has accepted ICJ's compulsory jurisdiction only in respect of 'the Suez Canal and the arrangements for its operations'.

92 In 1978, the ICJ ruled that it had no jurisdiction to hear a dispute brought by Greece against Turkey concerning the delimitation of the CS in the Aegean. See Aegean Sea Continental Shelf (Greece $v$ Turkey), ICJ Rep 1978.

93 Pursuant to Article 20 of the Statute of the International Tribunal for the Law of the Sea, ITLOS can resolve disputes in respect of 'all matters specifically provided for in any other agreement which confers jurisdiction on' it. See www.itlos.org/fileadmin/itlos/documents/basic_texts/statute_en.pdf accessed 25 August 2020.

94 The three maritime delimitation cases resolved by ITLOS to date are: Dispute Concerning Delimitation of the Maritime Boundary between Bangladesh and Myanmar in the Bay of Bengal (Bangladesh/ Myanmar), Dispute Concerning Delimitation of the Maritime Boundary between Ghana and Côte d'Ivoire in the Atlantic Ocean (Ghana/Côte d'Ivoire), and Dispute Concerning Delimitation of the Maritime Boundary between Mauritius and Maldives in the Indian Ocean (Mauritius/Maldives). For details of the cases see www.itlos.org/cases/list-of-cases accessed 25 August 2020. Five maritime boundary cases have been administered by the PCA to date. These are [2001-01] Eritrea-Ethiopia Boundary Commission, [2004-02] Barbados v. Trinidad and Tobago, [2004-04] Guyana v. Suriname, [201016] Bay of Bengal Maritime Boundary Arbitration between Bangladesh and India and [2012-04] 
PCA states party to the dispute are able to appoint the members of the arbitral tribunal (typically five), whereas the 15 judges of the ICJ are appointed by the UN General Assembly; (3) the majority of maritime boundary disputes have been resolved by the ICJ; and (4) states are not required to pay the costs of proceedings before the ICJ. ${ }^{95}$

In this regard, it should be noted that none of the delimitation agreements so far agreed in the East Mediterranean region provide for an enforceable right to resolve disputes thereunder by a third-party binding dispute resolution mechanism. ${ }^{96}$ In other words, even between Israel and Cyprus and Cyprus and Egypt there is no agreed enforceable mechanism to resolve disputes should they arise under the EEZ agreements.

\subsection{Obligation to make every effort to enter into provisional arrangements such as Joint Development Agreement (JDAs)}

As noted above, the states of the East Mediterranean are not obliged to resolve their delimitation disputes. They are, however, pursuant to Articles 74(3) and 83(3) of UNCLOS, which are seen as reflective of CIL, obliged to 'make every effort to enter into provisional arrangements of a practical nature' pending agreement on final delimitation. Although not required to reach an agreement under CIL, states are obliged under general principles of international law as reflected in Article 300 of UNCLOS to conduct negotiations to reach a provisional arrangement in good faith. ${ }^{97}$ The ICJ made clear in the North Sea Continental Shelf Cases that this obligation required states to 'enter into negotiations with a view to arriving at an agreement' and 'not merely to go through a formal process of negotiation' ${ }^{98}$ Moreover, it said that the negotiations had to be 'meaningful, which will not be the case when either [state] insists upon its own position without contemplating any modification of it'. 99 Nevertheless, it also made clear that the obligation to negotiate did not imply an obligation to reach an agreement. ${ }^{100}$ Examples of provisional arrangements agreed amongst states around the world pending a delimitation agreement which have been strongly recommended by the ICJ and other international tribunals include (1) a moratorium on all activities in overlapping areas; (2) joint development zones (JDZ); (3) special areas for fisheries; (4) provisional delimitation; and (5) bilateral co-operation regarding,

Arbitration Between the Republic of Croatia and the Republic of Slovenia. For details of the cases see https://pca-cpa.org/en/cases accessed 25 August 2020.

95 Amongst the countries in the East Mediterranean region, Israel is probably the only country that would not be prepared to refer its delimitation disputes to the ICJ. In 2003, the ICJ in its Advisory Opinion found Israel in breach of international law for continuing to build the wall. See Legal Consequences of the Construction of a Wall in the Occupied Palestinian Territory, Advisory Opinion 136 (ICJ 2004).

96 The agreements provide for arbitration whose nature, scope and procedural rules are to be agreed between the states.

97 See eg North Sea Continental Shelf Cases (FRG v. Den.; FRG v. Neth.), ICJ Rep 1969, 47. www. worldlii.org/int/cases/ICJ/1969/1.html accessed 25 August 2020, where in para 86 the ICJ considered the obligation to negotiate in good faith 'a principle which underlies all international relations'. It went on to say that this obligation 'is moreover recognized in Article 33 of the Charter of UN as one of the methods for the peaceful settlement of international disputes'. See Rainer Lagoni, 'Interim Measures Pending Maritime Delimitation Agreements' (1984) 78(2) The American Journal of International Law 345 and 355 and in particular n 60, 61 and 62; Brownlie (n 72).

98 North Sea Continental Shelf Cases (n 97) para 85(a).

99 Ibid.

100 Ibid, para 87. 
for example, maritime environment protection. ${ }^{101}$ A JDA is an agreement pursuant to which, usually, two states agree to develop and share jointly in agreed proportions the oil and/or gas found within the overlapping zone of the seabed and subsoil of the EEZ or CS. ${ }^{102}$ Although energy companies are not parties to JDAs, they are frequently the driving force for their conclusion. This is because JDAs are an important mechanism for providing a stable legal regime for undertaking exploration and exploitation activities in otherwise disputed maritime areas. Although international law does not impose an obligation on states in the region to enter into JDAs, Schofield and BeckerWeinberg, amongst others, show that such agreements have emerged as an important mechanism for overcoming deadlock in cases of overlapping maritime boundary claims. $^{103}$

There are at present about 24 JDAs around the world enabling oil and gas exploration in disputed maritime zones. ${ }^{104}$ Most JDAs expressly provide that they are provisional in nature and that their conclusion is without prejudice to maritime delimitation between the countries. They vary in form and complexity. For example, the Saudi Arabia-Bahrain JDA of 1958 contains only a single article whereas the Australia-Indonesia Timor Gap JDA of 1989 contains 34 articles and four annexes.

Bastida and others have grouped JDAs into the following three categories: (1) Model I - where each state retains authority over the JDZ and delegates no or minimal power to the joint authority; (2) Model II - where a joint authority with licensing and regulatory powers is appointed to manage the exploration and exploitation of the JDZ; and (3) Model III - where one of the states manages the development of the JDZ, with the other state's participation confined to revenue sharing and monitoring. Typically, a JDA contains the following provisions: (1) delimitation of the JDZ; (2) a sharing of resources; (3) management of the JDZ; (4) an operator and contractor; (5) dispute resolution; and (6) duration of the agreement.

101 By way of example, see the ICJ decision in North Sea Continental Shelf Cases (n 97) 52, and the separate opinion of Judge Jessup in the same case, 66-67. Conciliation Commission on the Continental Shelf area between Iceland and Jan Mayen: Report and recommendations to the governments of Iceland and Norway, Decision of June 1981, see https://legal.un.org/riaa/cases/vol_XXVII/1-34.pdf accessed on 18 October 2020.

102 JDAs are fundamentally different from unitisation agreements. Unitisation generally takes places when hydrocarbon resources have been discovered in an area that has a defined maritime boundary and relates to one or more deposits that straddle the boundary. On the other hand, a JDA is agreed where the EEZ/ CS delimitation has not yet been agreed between the countries but there is a willingness and desire to develop the resources in the disputed area before it is so delimited. In contrast to a unitisation agreement, a JDA normally covers a relatively large area and requires the establishment of a complex legal regime for licensing, exploration and development.

103 Clive Schofield, 'Defining areas for joint development in disputed waters' in Shicun Wu and Nong Hong (eds), Recent Developments in the South China Sea Dispute: The Prospect of a Joint Development Regime (Routledge 2014) 78-98; see also Vasco Becker-Weinberg, Joint Development of Hydrocarbon Deposits in the Law of the Sea (Springer 2014); Thomas A. Mensah, 'Joint Development Zones as an Alternative Dispute Settlement Approach' in Rainer Lagoni and Daniel Vignes (eds), Maritime Delimitation (Koninklijke Brill 2006) 143-151.

104 For a detailed discussion of the different examples of JDA see Ana E. Bastida and others, 'Cross-Border Unitization and Joint Development Agreements: An International Law Perspective’ (2007) 2 Houston Journal of International Law 255. 


\subsubsection{Delimitation OF THE JDZ}

A JDA delimits the JDZ by setting out the geographical coordinates joined by appropriate lines. As there will also be a depth element to the area - being the sea, seabed and subsoil - the delimitation will also need to take this into account.

In a Model I JDA, the JDZ is divided into subzones in respect of which each of the countries will license concessionaires under its own laws. In Model II JDAs, the joint authority will draw up the contract areas in respect of which it will then negotiate and conclude production sharing or other agreements with concessionaires. The Timor Gap Treaty of 1989 between Indonesia and Australia combines Model I and Model II agreements in that the JDZ was divided into three areas, with Australia having jurisdiction in Area B and Indonesia in Area C, with Area A under their joint control. ${ }^{105}$ It is common in both types of JDAs to provide for a unitisation agreement to develop fields that straddle the border of the JDZ and the maritime area of only one of the countries, where such a field is exploitable for both sides.

\subsubsection{SHARING OF RESOURCES}

The key to the success of a JDA is for the terms concerning the sharing of resources to be considered equitable by both states. Typically, this means that the JDA agreement provides that resources are to be shared equally. However, different approaches to sharing of resources can be observed in JDA agreements agreed to date, driven by the specificity of the JDZ case in question. In some instances a JDA will provide for the sharing of other resources, besides oil and gas, such as fisheries and minerals. One such example is the agreement between Guinea, Bissau and Senegal of 1993. In the future, consideration regarding the use of the sea bed in the JDZ for tidal, CCS and renewable projects should also be considered when drawing up a JDA.

\subsubsection{Management of THE JDZ}

As noted above, in a Model I JDA each state issues licenses for exploration and development in respect of its subzone of the JDZ. Criminal jurisdiction will also be accorded to each country in their respective subzone. In a Model II JDA neither state is directly responsible for the management of the gas development and neither is able to directly choose its own concessionaires. Instead, both states delegate the power they have in respect of such management, and in some cases their actual right to the resources, to a single body, typically named as a joint authority. Although in many ways a Model II JDA provides for a very simple solution in terms of management, there might be a real reluctance, from a political point of view, for states to delegate so much power to a joint authority as a joint authority is usually incorporated under the law of each state and international law. The nature and scope of the powers accorded to the joint authority will depend on inter alia the specificity of the development in question and the history of the relations between the states. Typically, it will be accorded the legal capacity to enter into production sharing or other type of agreements with

105 The text of the 1989 Treaty between Australia and the Republic of Indonesia on the Zone of Cooperation in an area between the Indonesian Province of East Timor and Northern Australia (1989 Timor Gap Treaty). https://cil.nus.edu.sg/wp-content/uploads/formidable/14/1989-AustraliaIndonesia-Timor-Gap-Treaty.pdf accessed 25 August 2020. 
concessionaires to explore and develop the JDZ. The joint authority may also have the power to draw up (1) the contract areas within the JDZ in respect to which it will then negotiate and agree production sharing or other agreements; (2) the fiscal and tax framework for the area; (3) the health and safety and other administrative regulations; and (4) the pollution prevention and marine protection measures. Each state typically appoints an equal number of members to the joint authority. There are some advantages in providing for a multi-tiered model of management of the JDZ, where the day-to-day management is given to the joint authority and the more political and strategic decisions are accorded to a joint ministerial council of which members are typically ministers of either state. In a Model III JDA, one of the states manages the JDZ on behalf of both of them. Any revenue collected is, after deduction of agreed and verified expenses, shared with the non-managing state in the agreed proportions. Provided that the nonmanaging state is happy to trust the managing state to pass on its agreed share of the benefit, this model is highly commendable because of its simplicity.

\subsubsection{OPERATOR AND CONTRACTOR}

In a Model I JDA, each state will appoint a concessionaire in respect of their zone of the JDZ. Between the two concessionaires, one will be appointed as the operator of the entire JDZ and the terms for the apportionment of expenses and production will be agreed between them. Each concessionaire will be liable to pay taxes to the state which has licensed it. Commonly, under this type of agreement a joint commission is appointed, although it will not have the authority to resolve disputes. In a Model II JDA, the production sharing or other types of concession contracts are entered into between the joint authority and the concessionaire.

\subsubsection{DisPUTE RESOLUTION}

Typically, JDAs provide for arbitration as a mechanism for dispute resolution. In recent years, multi-tiered dispute resolution clauses providing for mediation are increasingly being concluded. Sometimes the Model II JDA also sets out the mechanism for resolving disputes as between the joint authority and the concessionaire. This is not, however, necessary since such provision will be, in any event, included in the agreement they will have already entered into.

\subsubsection{Duration OF THE JDA}

Since exploration and exploitation of natural resources is capital intensive, the term of JDAs is typically for over 30 years.

The model JDA drafted under the auspices of the British Institute of International and Comparative Law in 1989 represents a good starting point for countries in the region looking to negotiate a JDA which will create a legal regime for the exploration and exploitation of oil and gas resources in the overlapping areas. ${ }^{106}$ A detailed study of

106 Hazel Fox (ed), Joint Development Offshore Oil and Gas, A Model Agreement for States for Joint Development with Explanatory Commentary (Vol. II, BIICL 1990) www.biicl.org/publications/jointdevelopment-of-offshore-oil-and-gas accessed 25 August 2020. 
the different structures and the wide variety of terms of JDAs concluded to date will also provide them with an invaluable tool to address the unique circumstances of their disputes and relations. The Treaty on the Joint Development of Petroleum and Other Resources in Respect of Areas of the Exclusive Economic Zone of the Two States, Nig.-São Tomé \& Príncipe, dated 21 February 2001, is a good example of a JDA for the countries in the region to consider when exploring this option. ${ }^{107}$

\subsection{Obligation to refrain from the threat or use of force}

Given that the heightened tensions in the East Mediterranean region in recent months have threatened to spill over into open military conflict, all the states in the region must recall their obligation pursuant to Article 2(4) of the Charter of the UN to 'refrain from the threat or use of force against the territorial integrity or political independence of any state'. ${ }^{108}$

\subsection{Obligation to refrain from unilateral exploitation of oil and gas reserves in disputed maritime areas}

An extensive body of academic authority can be cited in support of the existence of a CIL obligation to refrain from unilateral exploitation of oil and gas reserves in disputed maritime areas. ${ }^{109}$ According to Ong this obligation of restraint is arguably embodied in Article 83(3) of UNCLOS which obliges states to make every effort not to jeopardise or hamper the attainment of a final delimitation agreement. Since there is much debate on whether Article 83(3) of UNCLOS constitutes a rule of CIL, a better view is that a state's obligation to refrain from unilateral exploitation is a corollary of its CIL obligations, (1) where such oil and gas reserves are claimed to be located in the TS of another state as well, to refrain from threatening the territorial sovereignty of such other state (see section 7.5) and not to violate the inherent and exclusive right of such other state to explore and exploit its natural resources (see section 7.1); and (2) where oil and gas reserves are claimed to be located on the CS of another state as well, not to violate the latter's inherent and exclusive sovereign right to explore and exploit its own CS (see section 7.2).

By way of example, in the case of overlapping maritime areas where the coastal states are less than $400 \mathrm{NM}$ apart, each state has as a matter of principle exclusive and inherent rights to explore and exploit natural resources in the overlapping maritime zones. In such circumstances, the obligation of restraint is mutual and derives from the fundamental principles of international law of the sovereign equality of states. ${ }^{110}$ Or, put another way, it is a fundamental principle of international law that the territorial sovereignty of states does not extend beyond their borders and that any exercise of

107 Treaty between the Federal Republic of Nigeria and the Democratic Republic of SaoTome and Principe on the Joint Development of Petroleum and other Resources, in Respect of Areas of the Exclusive Economic Zone of the Two States (2001). www.un.org/Depts/los/LEGISLATIONANDTREATIES/ PDFFILES/TREATIES/STP-NGA2001.PDF accessed 25 August 2020.

108 Charter of the UN (n 88).

109 David M. Ong, 'Joint Development of Common Offshore Oil and Gas Deposits: "Mere" State Practice or Customary International Law?' (1999) 93(4) The American Journal of International Law 771.

110 See Article 2(1) of the Charter of the UN (n 88) which provides that the UN is based on 'the principle of the sovereign equality of all its Members'; see also Brownlie (n 72). 
exclusive authority across an international boundary would constitute a violation of another's territorial sovereignty or exclusive sovereign rights. ${ }^{111}$

To understand the nature and scope of the obligation to refrain from unilateral exploitation, it is important to understand the process of extracting natural gas and oil. Due to the fluid content of gas and oil deposits the extraction by one state of natural gas or oil at one point unavoidably changes the conditions in the whole deposit. In other words, in the case of a gas deposit straddling the boundary of two states one state cannot extract oil and gas reserves in one part of the deposit without depleting the reserves in the parts of the gas deposit belonging to another state. Accordingly, a state cannot exploit a straddling deposit without adversely affecting the economic interests of the other state. Since Ong has authoritatively demonstrated that the rule of capture is not a rule of international law, ${ }^{112}$ this means that under CIL states do not have a unilateral right to exploit natural resources in the case of straddling reserves. Furthermore, and by analogy, a state cannot unilaterally exploit an oil and gas reserve in a disputed maritime zones as this would violate the equivalent exclusive rights of the other state.

There is still some debate on whether the obligation of restraint is imposed only in respect of the exploitation of oil and gas reserves or extends also to exploration activities. Relying on the ICJ decision in the Aegean Sea Continental Shelf Case, Ong has suggested it could be argued that a state is not prohibited from conducting exploration activities - its duty being only to refrain from exploiting oil and gas resources. ${ }^{113}$ Since in that case the ICJ actually drew a distinction between, on the one hand, exploration activities that did not establish installations, and were thus temporary in character, and, on the other, more permanent exploration efforts which used stationary installations, Lagani has argued that the duty of restraint extends to both exploration, provided permanent installations were established, and exploitation. ${ }^{114}$ Since in the case of overlapping equal claims the opposing rights of states have to be balanced, the better view may be that the obligation of mutual restraint should be narrowly interpreted to prevent a state only from undertaking activities which cause irreparable prejudice to the interests of the other State. That notwithstanding, at least in the case of the States in the East Mediterranean region, there seems little doubt that even unilateral exploratory drilling may be the subject of strenuous protest. As discussed in section 6, Turkey's drilling near the island of Kastellorizo almost led to a military confrontation between Greece and Turkey in July 2020.

\section{Conclusion}

There was hope in the early 2010s that the gas discoveries in the East Mediterranean would act as a catalyst for peace in the region. However, in the words of Tzimitras 'the history of the East Mediterranean is a history of lost opportunities'. ${ }^{115}$ It is 'the zero-sum competition for the gas bonanza' which is, instead, shaping into a complex

111 North Sea Continental Shelf Cases (n 97) 22; Bastida (n 104) 363.

112 Rule of capture is a rule of law originally developed in the USA whereby the first person to 'capture' a resource owns that resource. Ong (n 109) 778.

$113 \mathrm{Ibid}, 798$.

114 Lagoni (n 97).

115 Tzimitras (n 50) 14. 
political, security and defence conflict. ${ }^{116}$ And, as discussed in section 6 , things could easily get out of control. The actions taken by all the actors in the region are exacerbating rather than reducing tensions. ${ }^{117}$ Security, economic and other alliances have hardened rather than softened opposing views.

The expectations amongst the local populations, spurred by politicians promising free education, healthcare and pensions for everyone even before any gas exploration and exploitation contracts were signed brought people onto the streets of Lebanon earlier this year, just as Total was about to start exploration drilling in block 4, north-west of Beirut. ${ }^{118}$ And with prospects for resolving the longstanding Cyprus dispute having all but faded, the challenges facing gas in the region seem insurmountable.

For the reasons discussed in sections 4 and 5, whether the countries in the region like it or not, the future of their exploitation and export of gas is inextricably linked to that of the others. Accordingly, rather than pointing fingers at each other all the countries in the region should recall their obligations to 'settle their international disputes by peaceful means in such a manner that international peace and security, and justice, are not endangered' and to 'refrain from the threat or use of force against the territorial integrity or political independence of any state'. 119

A reference of the delimitation disputes to the ICJ or to ad hoc arbitration under the auspices of the PCA in The Hague should be seriously explored and encouraged by international energy companies, the EU and the international community more generally. Israel and Cyprus were the first in the region to explore the possibility of referring the dispute regarding their percentage shares in the Aphrodite field to ad hoc international arbitration, in 2018. ${ }^{120}$ Although, as of the date of this article, the dispute has not been referred to arbitration and remains unresolved, their willingness to consider third-party binding arbitration to resolve delimitation disputes in the region is an important step in the right direction. It is also an example of good practice for other countries in the region to consider adopting.

The countries in the region should also be reminded by the international community and energy companies of their above-discussed obligations to (1) 'make every effort to enter into provisional arrangements of a practical nature until a delimitation agreement has been reached'; and (2) refrain from unilateral exploitation of gas resources in maritime zones of overlapping claims. They should also be encouraged to consider creating JDZs in overlapping maritime zones. To date this option has not been seriously explored by them. There have been, however, two initiatives regarding unitisation agreements. In 2006 Cyprus and Egypt signed a framework agreement for the development of straddling hydrocarbon resources albeit no development has yet taken place.

116 Geoffrey Aronson, 'Conflict expands in Eastern Mediterranean over gas riches' The Arab Weekly (19 January 2020) https://thearabweekly.com/conflict-expands-eastern-mediterranean-over-gas-riches accessed 25 August 2020.

117 Ibid.

118 Carol Nakhle, 'The Resource Curse Hits Lebanon Without the Resource' The Lebanese Center for Policy Studies (February 2020) https://lcps-lebanon.org/featuredArticle.php?id=268 accessed 25 August 2020.

119 As per Articles 2(3) and 2(4) of the Charter of United Nations see (n 88).

120 Sonia Gorodeisky and Amiram Barkat, 'Israel-Cyprus Gas Dispute Goes to Int'l Arbitration' Globes (1 May 2018) https://en.globes.co.il/en/article-israel-cyprus-gas-dispute-goes-to-intl-arbitration1001233992 accessed 25 August 2020. 
The discussions between Israel and Cyprus on the conclusion of a unitisation agreement have been ongoing since 2010. Agreement, as discussed in section 2, has not yet been reached. The development of joint export infrastructure is another option for promoting stability, prosperity and energy security in the region. A pipeline connecting Egypt with Turkey via Cyprus would be such a project.

However, for any of these options to be explored further, it will be necessary for the countries in the region to look beyond short-term political interests. Converging economic interests could act as a strong motivation, and perhaps a catalyst, for overcoming differences and creating inter-dependencies. In turn, co-operation in respect of gas development could act as a catalyst for broader co-operation. Perhaps gas can be a catalyst for peace after all? If not, the East Med gas bonanza is likely to be remembered as nothing other than short-lived hype. 